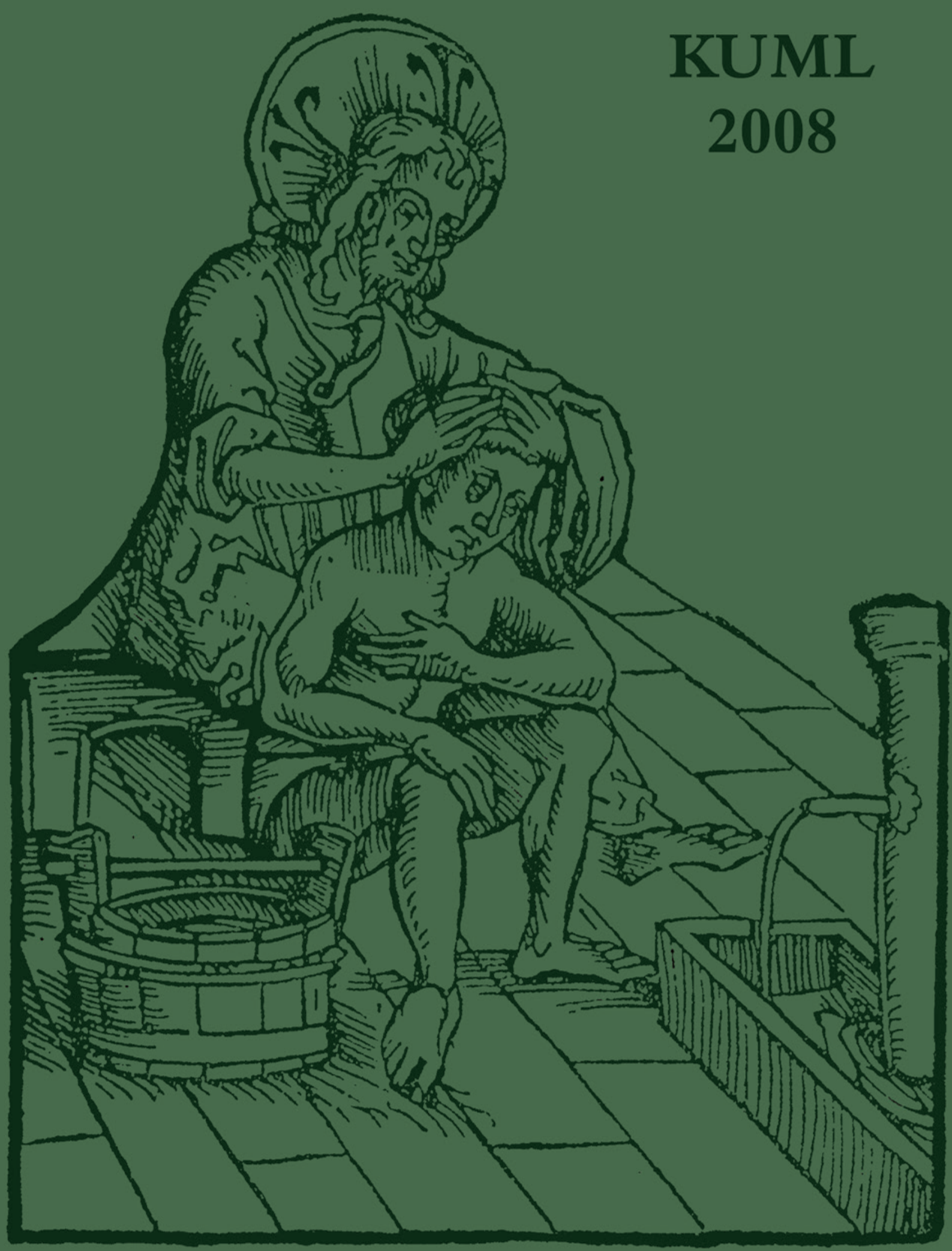




\section{KUML 2008 \\ Årbog for Jysk Arkæologisk Selskab}

With summaries in English

I kommission hos Aarhus Universitetsforlag 


\title{
Detektorfund og bebyggelse Det østlige Limfjordsområde i yngre jernalder og vikingetid
}

\author{
Af TORBEN TRIER CHRISTIANSEN
}

God dansk pløjemuld har igennem de seneste 30 år dannet skueplads for, hvad der kunne betegnes som en mindre revolution. Selvfølgelig i bedste danske ånd en fredelig én af slagsen, men dog med drastiske ændringer til følge. Siden midten af 70'erne har den private brug af metaldetektorer således i den grad "væltet« tidligere kendte arkæologiske fundbilleder med vidtrækkende konsekvenser for bl.a. opfattelsen af bebyggelsesmønstre og samfundsudvikling i specielt yngre jernalder, vikingetid og den tidlige middelalder.

Trods stor skepsis i opstartsfasen og enkelte skrækhistorier i medierne indimellem må den liberale danske lovgivning omkring privat brug af metaldetektorer betegnes som en succes. Denne har, når man sammenligner med flere af vore nabolande med mere restriktiv lovgivning på området, utvivlsomt bidraget til at bringe Danmark frem blandt de førende i studiet af bl.a. centralpladsdannelserne, de tidlige bydannelser og samfundene, som har fostret disse. ${ }^{1}$

I mange egne af landet har detektorentusiaster siden detektorens introduktion opsporet nye fundlokaliteter, og andre steder er mængden af fundmateriale fra allerede kendte lokaliteter blevet mangedoblet. Netop dette scenario har i høj grad udspillet sig i det østlige Limfjordsområde, og gør det faktisk fortsat. En række pladser langs både nord- og sydsiden af fjorden har således gennem årene »kastet« en mængde fund af sig, og i takt med det voksende antal fund har interessen fra professionelt hold for disse pladser været tiltagende. Ikke mindst set i relation til undersøgelserne af detektorpladsen Sebbersund i begyndelsen af 1990'erne og "totalundersøgelsen« af Bejsebakken i årene omkring årtusindeskiftet. ${ }^{2}$

Revolutionen har således også fundet vej til Nordjylland, men synes dog aldrig helt at have haft den samme indsatsmæssige effekt her som andre steder i landet. Helt fra detektoreventyrets start var indleveringerne fra Aalborg Historiske Museum ellers blandt de største fra hele landet, men detektoramatørernes indsats omkring den østlige Limfjord er her aldrig blevet fulgt op og videreud- 
viklet i samme grad, som det eksempelvis har været tilfældet på Sydøstfyn og Bornholm. Dette har bl.a. medført, at flere relativt rige detektorlokaliteter omkring Limfjorden endnu i dag er karakteriseret ved næsten at være uundersøgte, når man ser bort fra amatørernes overfladerekognosceringer med detektor. Det er derfor heller ikke overraskende, at disse pladser hidtil kun er blevet berørt enkelte gange i litteraturen, og da i sagens natur kun meget sparsomt. ${ }^{3}$

Givetvis har de mange kildekritiske problemer forbundet med et overfladeindsamlet materiale, indleveret af mange forskellige privatpersoner og fulgt af fundoplysninger af stærkt varierende kvalitet, ikke akkurat virket fremmende for processen omkring bearbejdningen af dette materiale. Det skal der imidlertid søges at råde bod på i det efterfølgende, og denne artikel rummer et forsøg på en systematisk fremstilling og en indledende bearbejdning af det forhistoriske detektormateriale fra det østlige Limfjordsområde. ${ }^{4}$ For flere af de implicerede lokaliteters vedkommende er der dog i høj grad tale om en midlertidig fundstatus, idet tilgangen af nye fund i flere tilfælde fortsat er stor. Hovedvægten er lagt på studiet af en håndfuld særligt rige lokaliteter tæt ved fjorden, og perioden yngre jernalder inklusiv vikingetid kommer naturligt $i$ fokus, idet den forhistoriske del af detektormaterialet i langt overvejende grad stammer fra dette tidsrum.

Der findes således i det østlige Limfjordsområde en mængde enkeltfundne metaller og spredte detektorpladser med ganske få fund, men en lille række pladser, der ligger som perler på en snor langs Limfjordens nord- og sydkyst, adskiller sig fra de øvrige ved et mærkbart rigere detektorfundmateriale. De aktuelle lokaliteter er følgende: Postgården, Humlebakken, Bejsebakken, Thulebakken, Sofiendal/Gl.Hasseris, Nørholm, Mellemholm, Sebbersund, Øland, Gjøl og Lindholm Høje (fig. 1). Som det har kunnet konstateres på andre lignende pladser i resten af Sydskandinavien, synes også detektorfundene fra disse almindeligvis at stamme fra oppløjede bebyggelsesflader, men endnu er der en række problemer forbundet med tolkningen af disse detektorlokaliteter. ${ }^{5}$ Blandt andet står det i dag klart, at der på Limfjordspladserne er et betydeligt misforhold mellem detektorfundenes spredning og udbredelsen af de underliggende arkæologiske anlægsspor. Fundene er på hovedparten af pladserne simpelthen spredt over et langt større areal, end man realistisk set vil kunne forvente dækket af bebyggelsesspor.

Som fundbilledet i dag tegner sig, taler meget for, at hovedparten af de metalrige pladser har haft et agrart fokus suppleret med specialiserede håndværk og handel, og indtil videre forekommer detektorpladserne omkring den østlige Limfjord at afspejle en bebyggelsesudvikling, som i nogen grad divergerer fra situationen i den sydøstlige del af landet. Nok har cirkulationen af metal- 


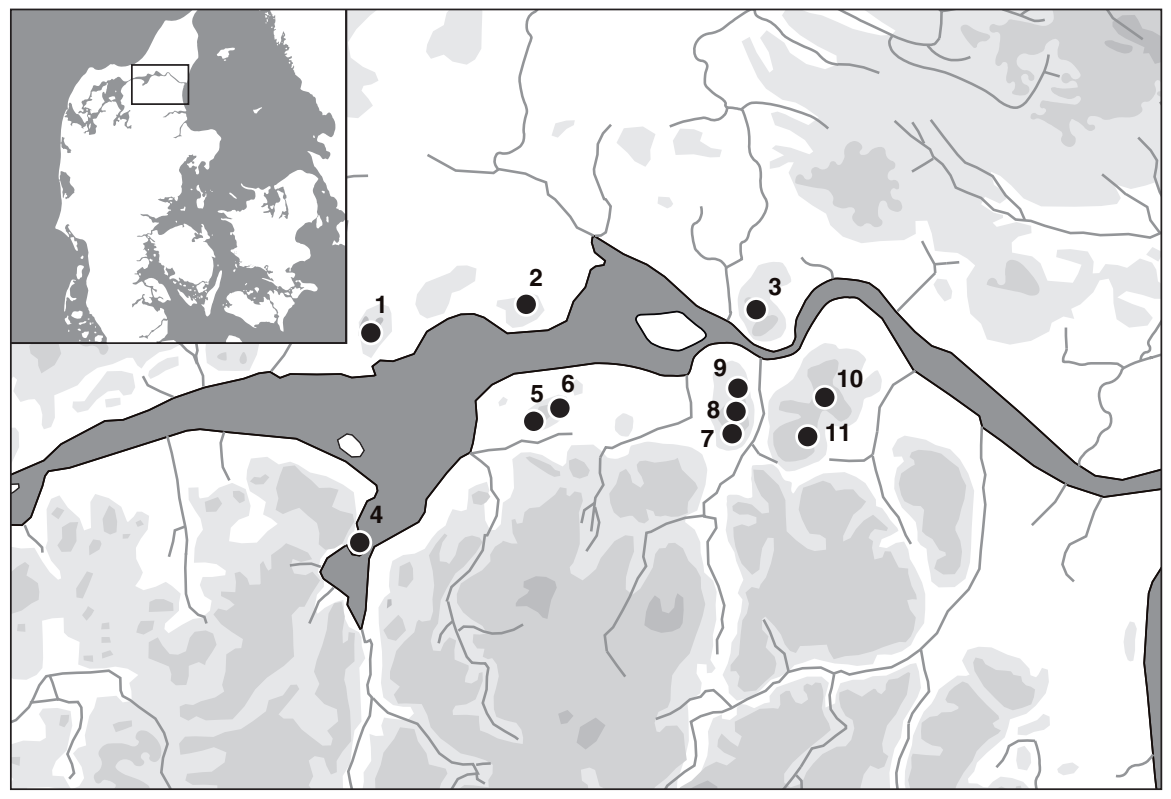

Fig. 1. De rige detektorpladser langs den østlige Limfjord. 1: Øland, 2: Gjøl, 3: Lindholm Høje, 4: Sebbersund, 5: Mellemholm, 6: Nørholm, 7: Sofindael/Gl.Hasseris, 8: Bejsebakken, 9: Thulebakken, 10: Humlebakken, 11: Postgården.

The rich detector sites by the Eastern Limfjord.

genstande generelt været høj i regionen, men detektormaterialet rummer langt overvejende periodens almindeligt forekommende bronzesmykker og udtrykker kun meget sparsomme spor af et egentligt hierarki de rige bebyggelser imellem. Det til trods for det faktum, at de "produktive« bebyggelser ligger ganske tæt i regionen.

\section{Den østlige Limfjord og det omkringliggende landskab}

Landskabet i den østlige Limfjordsregion er, som det ser ud i dag, kendetegnet ved stor variation. Selve Limfjorden udgør her, modsat det brede øhavslignende farvand mod vest, et smalt bugtende forløb med den ca. $2 \mathrm{~km}$ brede Nibe/Gjølbredning som eneste undtagelse. Dette smalle flodlignende forløb karakteriseres ved store lavvandede arealer gennemskåret af en dyb sejlrende i midten. Ind mod begge kyster aftager vanddybden gradvist, og i næsten hele området erstattes fjordbunden gradvist af lave fugtige engarealer. Hyppigst 
brydes denne harmoniske overgang mellem det marine element og fastlandet først flere hundrede meter eller længere inde i landet, og markante morænebakker skyder op. Bakkelandskabet langs begge kyster udgør dog ikke en jævn, massiv mur, men består derimod af større og mindre, isolerede bakkeøer adskilt af lave engarealer. Ofte i form af brede ådale. Bredden af det marineforland som adskiller bakkepartierne fra selve fjorden, varierer stærkt, og mens enkelte af bakkerne specielt ved fjordens smalleste sted mellem Ålborg og Nørresundby skyder sig tæt ud mod Limfjordskysten, er afstanden fra morænebakkerne og til Limfjordskysterne i den allerøstligste del af området stor. Her længst mod øst erstattes bakkelandskabet endelig helt til sidst af kilometervis af flade lave engarealer, før Limfjordens østligste forløb »Langerak» sluttelig løber ud i Kattegat.

Bevæger man sig en tand længere ind i landet forbi de kystnære morænebakkepartier i den østlige Limfjordsregion, er forskellen betydelig mellem landskaberne nordenfjords og søndenfjords. Syd for fjorden præges terrænet af store morænebakker adskilt af brede bugtende ådale, mens de kystnære bakkeøer nordenfjords i vid udstrækning erstattes af flade lavtliggende engarealer.

Fjordlandet fik groft set sit nuværende udseende for omkring 2000 år siden, og skal man således skabe et billede af den yngre jernalders Limfjordslandskab, ligner dette i grove træk nutidens. Dog er det klart, at specielt nyere tiders dræning af de hævede marine arealer slører billedet. Disse har i jernalderen formodentlig almindeligvis udgjort ufremkommelige vådbundsarealer, som har besværet adgangen til fjorden såvel som trafikken mellem bakkeøerne. Nordenfjords har bakkeøerne Øland og Gjøl endnu udgjort reelle øer i den lavvandede kystzone, og længere mod vest umiddelbart i tilknytning til Aggersborg har der formodentlig endnu været en sejlbar nordgående forbindelse mellem Limfjorden og Skagerrak via "Sløjen-kanalen«. Geologiske iagttagelser indikerer dog, at dennes nordlige munding allerede kort efter Kristi fødsel sandede til. Imidlertid forekommer det absolut ikke utænkeligt, at kanalen til trods herfor kan have været flittigt benyttet i nogen tid efter dette tidspunkt. Besværet ved en kort slæbetur er formentlig blevet opvejet ved en noget kortere rute, såfremt man kom nordfra, og Limfjorden var destinationen eller blot skulle passeres for eksempelvis at nå Østersøområdet, eller såfremt man fra Limfjordsområdet ønskede at sejle nordover. En trafik som synes underbygget af såvel stednavne som arkæologiske og historiske kilder. ${ }^{6}$

I den tidlige middelalder sander også Limfjordens vestlige munding til, og fjorden bliver reelt set en fjord. Ikke blot sejlruter ændres, men også flora og fauna i fjorden forandres. Utvivlsomt med store konsekvenser for økonomi og erhvervsstruktur i hovedparten af Limfjordsområdet. 


\section{Fundlokaliteterne}

De rige detektorpladsers topografiske placering ligner for hovedpartens vedkommende hinanden til forveksling. Alle på nær Sebbersund er således knyttet til de store morænebakker langs Limfjordens nord- og sydkyst. Typisk rummer hver bakke én plads kendetegnet ved en koncentration af detektorfund omkring bakketoppen.

På de store bakkedrag »Bejsebakken« og »Nørholm» er der dog også separate fundlokaliteter et stykke nede ad bakkernes sydvendte sider, nemlig henholdsvis Sofiendal/Gl. Hasseris ved Bejsebakken og lokaliteten »Mellemholm» nær foden af Nørholmbakkeøen. ${ }^{7}$

Med en placering på et plateau knyttet til en lav sandet odde næsten helt ude ved selve Limfjordskysten afviger Sebbersundpladsen markant fra de øvrige rige pladser. Odden ligger blot $5 \mathrm{~m}$ over havniveau og findes på den østlige Limfjords bredeste sted, netop hvor et smalt sund forbinder selve Limfjordens hovedforløb med Halkær Bredning - en lille inderfjord ved mundingen af Halkær å.

Fundantal og afsøgningsniveau varierer betydeligt de enkelte lokaliteter imellem. Fra Bejsebakken, Thulebakken og Lindholm Høje blev de første fund allerede indleveret sidst i 70'erne og først i 80'erne, og herfra er der i nævnte rækkefølge indtil videre blevet registreret 229, 53 og 63 danefæ-metaller fra jernalderen

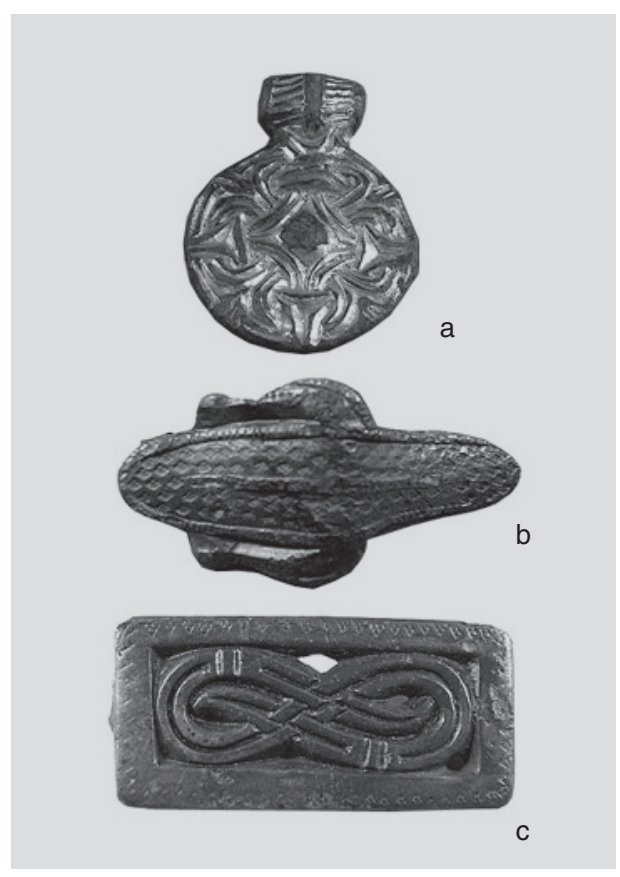

Fig. 2. Detektorfund. a: Forgyldt hængesmykke - Postgården. b: Næbfibel Humlebakken, c: Rektangulær pladefibel - Postgården. Målestok 1:2.

Detector finds. a: Gilded pendant Postgården, b: Beak brooch - Humlebakken, c: Rectangular plate brooch Postgården. 
Fig. 3. Detektorfund fra Nørholm. a: Oval skålformet spænde, b: Fuglefibel i gennembrudt arbejde c: Trefliget spænde. Målestok 1:2.

Detector finds from Nørholm. a: Tortoise brooch, b: Open-work bird brooch, c: Trefoil brooch.

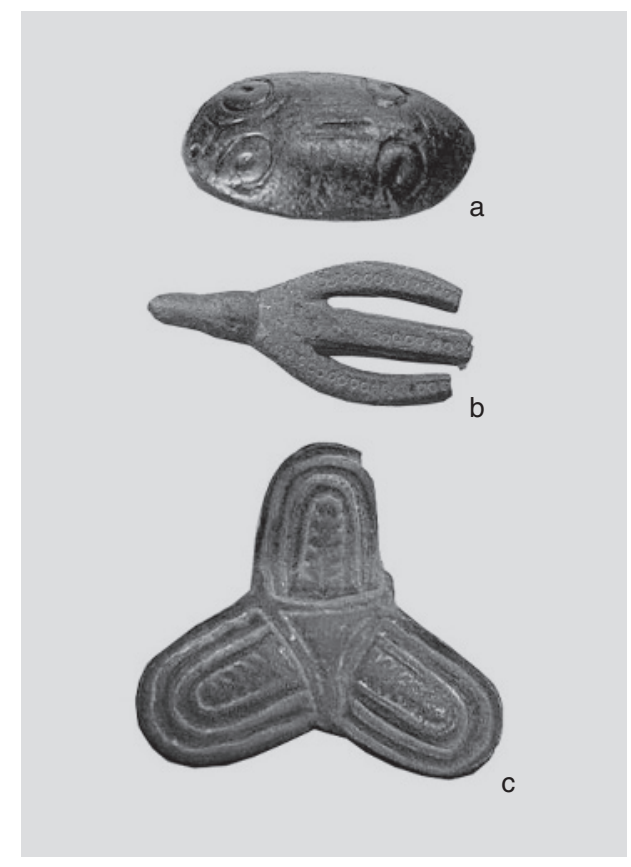

I midten af 80'erne udvidede detektorfolkene deres virkeområde til også at omfatte bakkerne ved Humlemarken og Sofiendal/Gl. Hasseris, og herfra er hidtil blevet indleveret henholdsvis 24 og 31 jernalderfund.

Mod slutningen af 80'erne bevæger detektorentusiasterne sig længere og længere væk fra de gamle kendte bakketoppe i og ganske nær Aalborg, og de første indleveringer fra Sebbersund, Postgården, Mellemholm og Nørholm indløber til Aalborg Historiske Museum. Sebbersund og Postgården tegner sig for henholdsvis 69 og 28 detektorfundne metalgenstande fra jernalderen. Mens der fra Nørholm og Mellemholm indtil videre er blevet indleveret 139 og 41 jernaldergenstande. Modsat de to førstnævnte bliver der imidlertid fortsat årligt indleveret betydelige mængder fund fra Nørholm og Mellemholm.

Endelig er der i 90'erne begyndt at indløbe fund fra Øland og Gjøl. Endnu er antallet af jernalderfund herfra relativt beskedent, men fundmængden vokser kontinuerligt. Fra Øland kendes indtil videre i alt 149 »ikke-monetære« danefæfund, hvoraf kun 23 kan henføres til jernalderen. Gjøl tegner sig udover en del mønter fra middelalderen for 65 genstande, hvoriblandt der optræder beskedne 11, som lader sig henføre til jernalderen.

Enkelte af de rige detektorpladser var dog kendte arkæologiske fundlokaliteter allerede inden metaldetektorens fremkomst i 70'erne. Lindholm Høje har således været genstand for arkæologiske undersøgelser ad flere omgange, og 
allerede tilbage i 1800 -tallet var pladsen genstand for de første privatfinansierede udgravninger. Senere har Nationalmuseet under flere kampagner undersøgt gravpladsen og dele af bebyggelsen på stedet. ${ }^{8}$ Også Bejsebakken var allerede en gammel kending ved metaldetektorens fremkomst. I 1950'erne indløb de første overfladefundne metalgenstande således fra bakketoppen, og ikke længe efter blev en mindre del af jernalderbebyggelsen på stedet udgravet. $^{9}$

I flere tilfælde kan fundmaterialet frembragt af detektorfolkene således suppleres med informationer indhentet ved regulære arkæologiske udgravninger. Undersøgelsesniveauet varierer dog kraftigt lokaliteterne imellem. Ekstremerne repræsenteres af Bejsebakken, Øland og Gjøl. Mens førstnævnte således må betragtes som noget nær totaludgravet, er der stort set ikke foretaget så meget som bare en eneste mindre undersøgelse på Gjøl eller Øland. ${ }^{10}$ Heller ikke Nørholm, Mellemholm eller Thulebakken er særligt velundersøgte, idet her kun er foretaget mindre forundersøgelser og små lokale udgravninger af anlæg ældre end yngre jernalder.

På Humlebakken og Sofiendal/Gl.Hasseris er der foretaget små sporadiske undersøgelser af bl.a. bebyggelsesspor fra yngre jernalder, men ikke undersøgelser der kan sidestilles med udgravningerne foretaget på Lindholm Høje, Sebbersund og Postgården. Især på Lindholm Høje er der blevet gennemført omfattende undersøgelser, men også en betragtelig del af bebyggelsen med handelsplads, trækirke og gravplads ved Sebbersund er undersøgt. ${ }^{11}$ Senest er den nordlige del af bebyggelsen ved Postgården blevet undersøgt og dele af en tilhørende gravplads fra germansk jernalder længere mod øst.

\section{Materialesammensæetning - Kronologiske tendenser}

Det registrerede detektormateriale fra regionen omfatter udelukkende danefæ, men dette er absolut ikke nogen stabil størrelse. Detektorfolkets succes har således i de senere år ført til reguleringer af »danefæ-begrebet«. Blandt andet har den stigende arbejdsbyrde med metalfundene tvunget Nationalmuseet til løbende justeringer af danefævurderingerne. Konsekvensen har været en skærpelse af kriterierne, som betyder, at en betydelig del af dét, Nationalmuseet tidligere ville have betegnet "danefæ«, i de senere år i stigende grad er blevet returneret til lokalmuseerne (fig. 4).

Dette overskudsmateriale fra de aktuelle pladser savner endnu nærmere registrering og typebestemmelse, hvorfor det ikke har kunnet inddrages $i$ denne undersøgelse. Det har dog udelukkende indflydelse på de nyere fundlokaliteter Øland, Gjøl, Nørholm og Mellemholm, hvis fundmateriale på den 


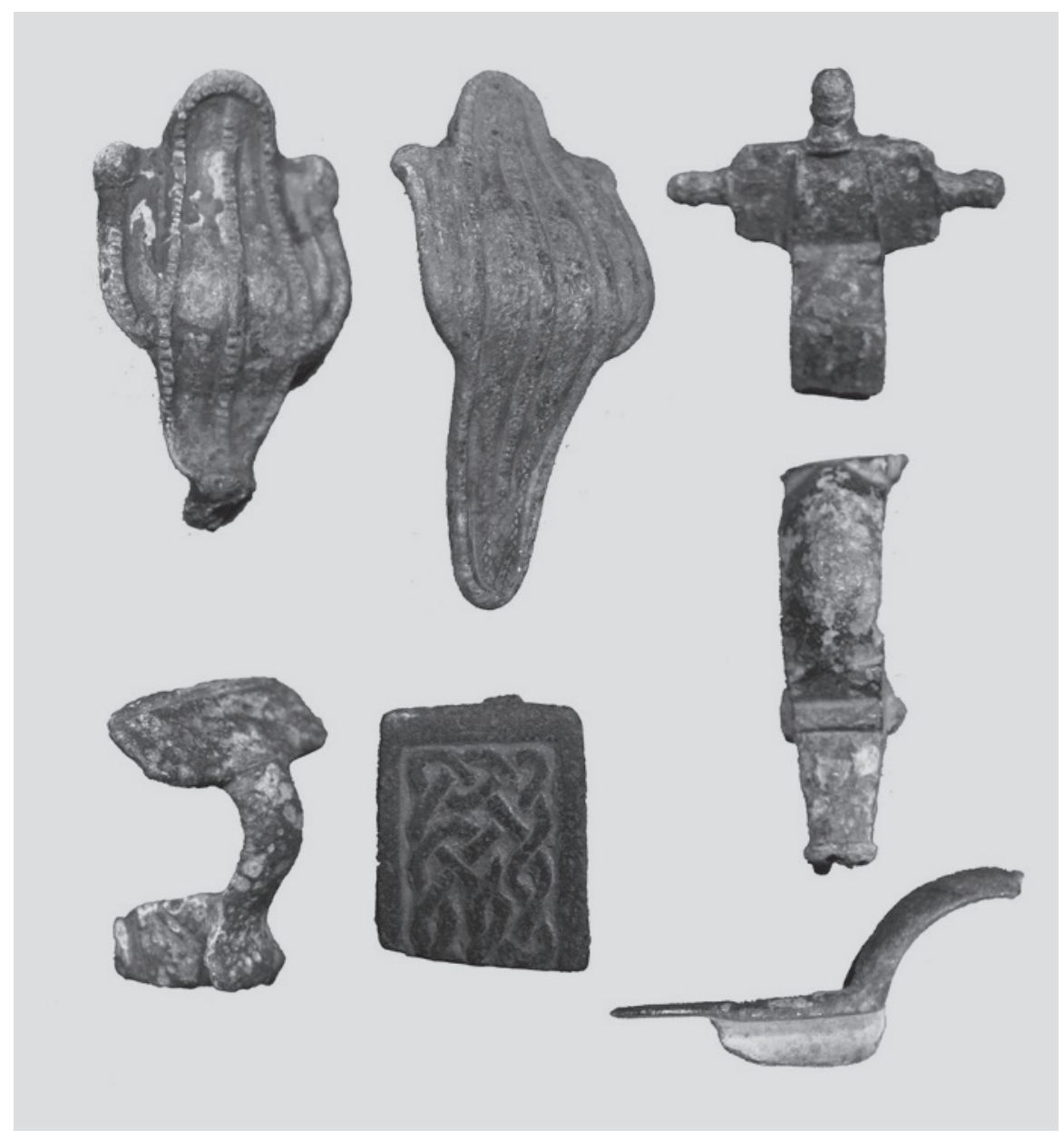

Fig. 4. Bronzer fra Nørholmbakkeøen returneret fra Nationalmuseet. Ikke erklæret »danefæ«. Målestok 1:1.

Bronzes from Nørholm hill returned by the National Museum. Not declared as "treasure trove".

baggrund må forventes at være lidt underrepræsenteret i forhold til de »ældre« fundpladser fra tiden, da euforien over metalfundene endnu herskede.

Helt overordnet rummer materialet uhyre få ædelmetaller. Langt den overvejende del er bronzer, hvoriblandt der ikke sjældent optræder især fortinnede eksemplarer men også jævnligt forgyldte genstande. Ikke mindre end 478 af 709 aktuelle danefæfund fra de udvalgte pladser udgøres af fibler af forskellig art - i alt 67,5 \% af det samlede fundmateriale (fig. 5). Der er dog en markant 


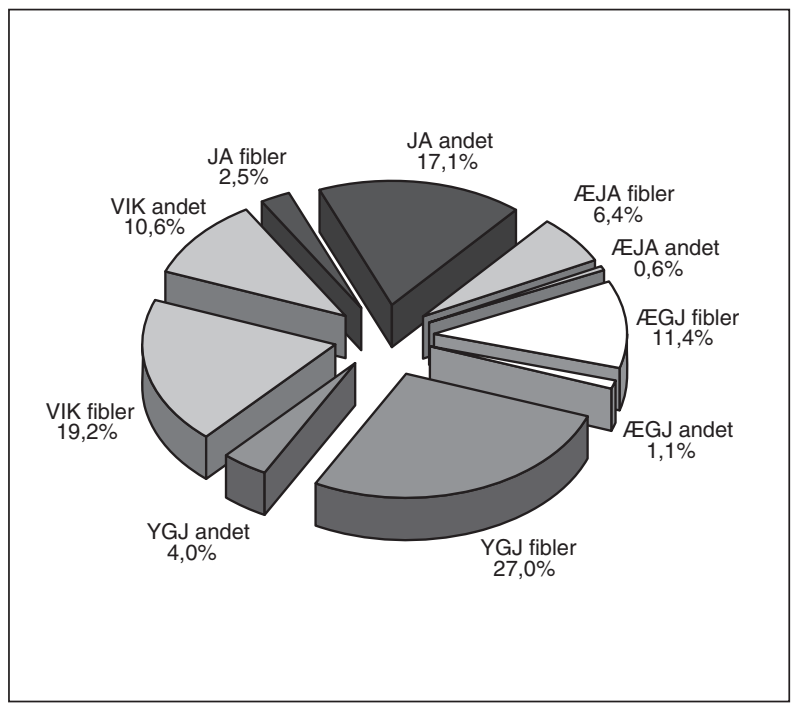

Fig. 5. Sammensætning af detektormaterialet fra de rige detektorpladser. Æja $=$ ældre jernalder, $Æ g j=$ ældre germansk jernalder, Ygj = yngre germansk jernalder, Vik $=$ vikingetid, $\mathrm{ja}=$ jernalder.

Composition of detector assemblages from the rich detector sites. Æja $=$ Early Iron Age, $Æ g j=$ Early Germanic Iron Age, Ygj = Late Germanic Iron Age, $\mathrm{Vik}=\mathrm{Vi}$ king Age, Ja = Iron Age.

tendens til, at andelen af andre fundtyper stiger, jo yngre materialet bliver. Mens metallerne således fra ældre germanertid altovervejende består af rimeligt ordinære bronzer, langt hyppigst af korsformede fibler, synes materialet fra yngre germanertid betydeligt mere varieret. Fortsat domineret af fibler men nu med stor typemæssig variation og store kvalitative forskelle. Samme udvikling fortsættes i vikingetidsmaterialet, som endvidere præges af en tiltagende mængde metalfund hjemmehørende uden for smykkesfæren.

Hovedparten af lokaliteterne kendetegnes ved et fundmateriale indeholdende fibler, som repræsenterer næsten hele jernalderen. Hyppigt kun i form af enkelte fibler fra ældre jernalder og tiltagende antal i yngre jernalder med kulmination i yngre germanertid (fig. 6).

Denne udprægede kontinuitet ses dog ikke på alle fundlokaliteterne. Forholdene på Øland, Gjøl og Sebbersund afviger markant fra dette mønster. Her er der næsten udelukkende fremkommet fund fra yngre germansk jernalder og vikingetid. Fra Øland kendes et enkelt fragment af et armbånd fra romersk jernalder, ligesom der fra Sebbersund trods det ellers righoldige fundmateriale kun er indleveret tre ældre germanertidsfibler, og heller ikke yngre germanertid er stærkt repræsenteret i fundmaterialet herfra. Tydeligvis topper aktiviteterne på Sebbersundpladsen først i vikingetiden.

Både Øland og Gjøl hører imidlertid til blandt de nyere fundlokaliteter, og må formodes dårligst afsøgt. Materialet herfra er endnu så sparsomt, at det må anses for yderst usikkert, om det er repræsentativt. Sebbersundmaterialets manglende fund fra ældre jernalder og hovedvægt i vikingetid afspejler dog 

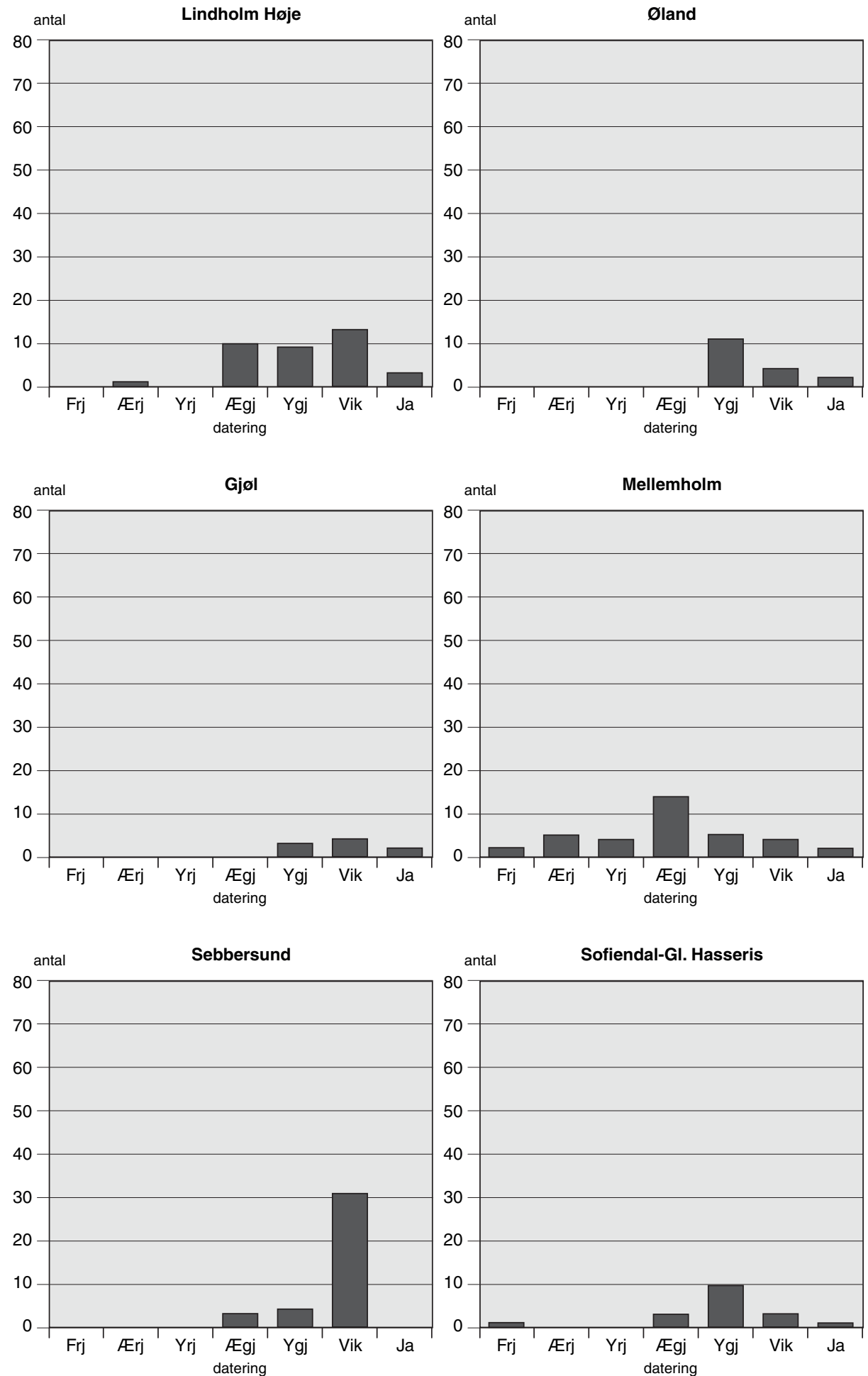

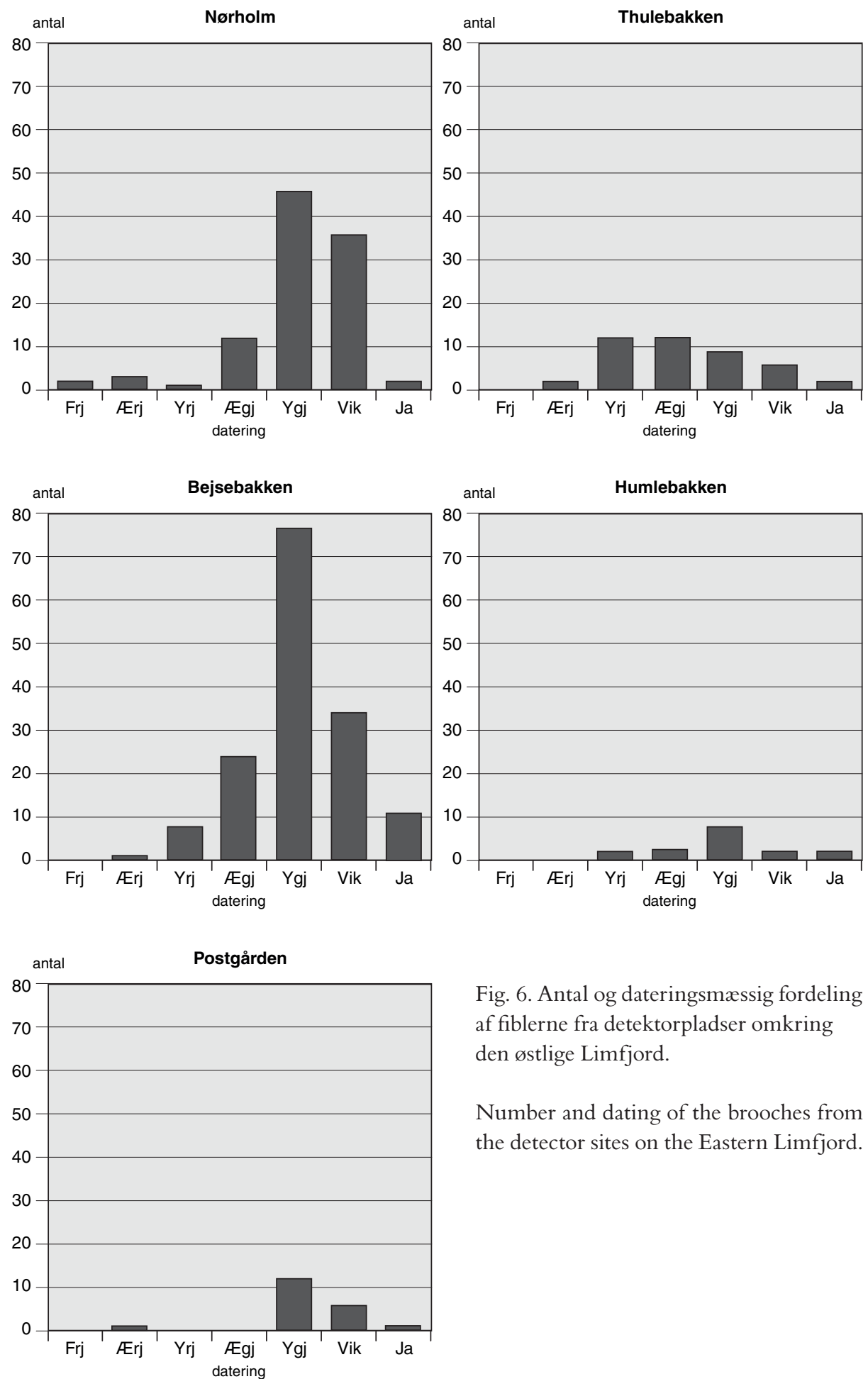

Fig. 6. Antal og dateringsmæssig fordeling af fiblerne fra detektorpladser omkring den østlige Limfjord.

Number and dating of the brooches from the detector sites on the Eastern Limfjord. 
givetvis virkeligheden, og stort set samme mønster ses i et lignende fibelspekter lavet i 90'erne på basis af både udgravede og detektorfundne fibler. ${ }^{12}$ Den kronologiske opdeling er blot i forbindelse med sidstnævnte mere finmasket, hvorfor det ved denne undersøgelse endvidere kunne illustreres, at fundmængden rent faktisk først topper i 1000-tallet, ligesom det påvises, at brugen af pladsen tilsyneladende ophører først i 1100-tallet.

I relation til kontinuitetsspørgsmålet skal det ydermere tilføjes, at der i forbindelse med alle de her behandlede detektorpladser også er fremkommet materiale af yngre dato. Dette yngre materiale svinger fra nogle få middelalderog renæssancemetaller til, som ved tilfældet Nørholm, at omfatte adskillige hundrede, ja betydeligt mere end 1000 såfremt mønter også medregnes. Også ved Bejsebakken, Thulebakken og Sofiendal/Gl.Hassseris er specielt møntmaterialet fra middelalder og historisk tid talrigt.

Man har dog ikke ved udgravningerne på Bejsebakken kunnet påvise anlæg yngre end vikingetiden, ligesom der i det endnu ubearbejdede fundmateriale fra udgravningen af Bejsebakkebebyggelsen generelt synes at optræde meget få vikingetidsgenstande og tilsyneladende ingen fra periodens yngste del, dvs. tiden efter ca. år 950. Til gengæld er middelalderlige kulturlag fra Aalborg tidligere blevet dumpet på markerne ved Hasseris i det vestlige Aalborg, og det synes mest nærliggende at henføre hovedparten af de middelalderlige fund og muligvis også de sene vikingetidsgenstande til denne affaldstransport. Mindre metalgenstande, som er blevet tabt eller smidt bort i middelalderbyen, er således sammen med organisk affald blevet spredt på markerne i omegnen. ${ }^{13}$

I de fleste af de øvrige tilfælde er der vel i forbindelse med middelalderfundene også stor sandsynlighed for, at disse i virkeligheden repræsenterer fortsat brug af jordene som gødskede agerbrugsarealer snarere end reel bebyggelse på selve fundstedet. Der er da også et påfaldende sammenfald mellem de rige detektorpladser og de romanske kirker på bakkeøerne. Almindeligvis findes kirkerne i umiddelbar tilknytning til de detektorfundsrige arealer. På Øland er det dog i stedet øens Benediktinerkloster grundlagt ca. 1175, som er nabo til detektorpladsen. Kun i forbindelse med Hasseris-bakkeøen med Thulebakken, Bejsebakken og Gl. Hasseris/Sofiendal savnes de tidlige kristne bygningsværker.

Med hensyn til den kontinuerlige anvendelse af arealerne op i middelalderen synes dette også i høj grad at gøre sig gældende ved Øland, Gjøl og Nørholm. Det middelalderlige fundmateriale fra disse lokaliteter fremstår imidlertid umiddelbart meget omfangsrigt, når man tager i betragtning, at der i disses nærmeste omgivelser ikke findes større handelsbyer, der kan føres tilbage til middelalderen. Skal man således tolke alene på basis af detektorfundene, synes 
disse lokaliteter ikke at miste deres centrale funktion i vikingetid eller tidlig middelalder.

I forbindelse med diagrammet for Nørholm bør det tilføjes, at dette i øvrigt i sammenligning med f.eks. Bejsebakkediagrammet er en smule misvisende, bl.a. som følge af ændret registreringspraksis på Nationalmuseet, og en nøjere gennemgang af Nørholmmaterialet ville formentlig afføde et lidt forandret dateringsbillede, end det her fremsatte. ${ }^{14}$ Et billede som ville vise en fortsat stigning $i$ antallet af fibler op gennem hele yngre jernalder og ind i middelalderen, og ikke som vist i figur 6 en stagnation i vikingetiden. Det er da også en kendsgerning, at var ovennævnte diagrammer lavet på basis af det fulde genstandsmateriale og ikke blot på basis af fiblerne, ville dette faktisk være tilfældet uden yderligere "tilskud« til materialet.

Endelig udviser diagrammerne for Thulebakken og Mellemholm en lidt anderledes udvikling end den gængse. Disses fibelsammensætning ligner hinanden og er karakteriseret ved et jævnt stigende antal fibler op gennem ældre jernalder kulminerende i ældre germanertid og gradvist faldende gennem resten af yngre jernalder. På begge lokaliteter er der generelt fundet forholdsvis mange fibler fra ældre jernalder, og havde administreringen af danefæreglerne, som tidligere nævnt, ikke ændret sig, ville Mellemholm faktisk have tegnet sig for endnu flere. Det er i øvrigt interessant, at metalcirkulationen synes at svinde ind på både Thulebakken og ved Mellemholm i yngre germansk jernalder, hvor cirkulationen synes at accelerere på disse pladsers store nabo henholdsvis Bejsebakken og Nørholm. Skal man dømme ud fra metalfundene, er der dog fortsat aktivitet på de to førstnæunte gennem hele yngre jernalder.

Netop i yngre germanertid synes metalcirkulationen på Bejsebakken og Nørholm at hæve sig markant over de øvrige. Kompenseres dog for ældre germanertids omtrent 100 år mindre kronologiske spændvidde, fremstår accelerationen mellem ældre- og yngre germansk jernalder dog knap så markant, som man ved første øjekast kunne få indtryk af ved betragtning af diagrammerne.

\section{Lokal fundspredning - bopladsstørrelse og struktur}

Meget tyder på, at de massive detektorfund fra især yngre jernalder fra lokaliteterne omkring Limfjorden, og fra den resterende del af landet i øvrigt, i altovervejende grad stammer fra nedpløjede bebyggelsesflader. I forbindelse med de her behandlede lokaliteter er der fundet bebyggelsesspor i større eller mindre omfang på alle pladser, som har været genstand for mere omfattende undersøgelser, hvilket faktisk drejer sig om over halvdelen af detektorlokalite- 
terne, nemlig Postgården, Humlebakken, Bejsebakken, Gl.Hasseris/Sofiendal, Sebbersund og Lindholm Høje. På alle disse pladser er der imidlertid også gjort gravfund. Når man ser bort fra Lindholm Høje med sine hen imod 700 grave og Sebbersund med sin kristne gravplads, er der dog hyppigst tale om ganske få grave dateret til romersk jernalder. Ikke gravfund der umiddelbart indikerer tilstedeværelsen af større gravpladser under nedpløjning.

Grundet den fremherskende brandgravsskik i det nordjyske gennem store dele af yngre jernalder kunne man endvidere forvente en mængde varmebeskadigede genstande blandt detektorfundene, såfremt disse stammede fra marker med grave under erosion. Dette er dog ikke tilfældet.

Imidlertid skal detektormaterialet muligvis alligevel tolkes lidt mere nuanceret. Med fremkomsten af en gravplads umiddelbart øst for bebyggelsen ved Postgården har tvivlen om metalgenstandenes entydige tilknytning til bopladslag således meldt sig. Her er for nylig blevet udgravet dele af en gravplads med bl.a. brandgrave fra både ældre og yngre germansk jernalder, og ved en analyse af genstandsmaterialet fra brandgravene viste kun $17 \%$ af fundene af danefæklasse synlige spor efter at have været på ligbålet og flere kun meget svage spor efter denne sekundære varmepåvirkning. ${ }^{15}$ Samtidig er det værd at notere sig, at der blandt gravene fandtes gravanlæg fra yngre germansk jernalder anlagt direkte oven på den daværende markflade. Et træk som også var fremherskende på Lindholm Høje-gravpladsen, og som tillige kendes fra bl.a. Donbæk længere nordpå..$^{16}$ Resterne af sådanne gravpladser må på de opdyrkede marker i dag forventes næsten udelukkende at optræde i pløjelaget.

Stadig kan det dog undre, at detektormaterialet fra pladserne omkring den østlige Limfjord ikke indeholder flere varmebeskadigede genstande, og resultaterne af udgravningerne på de forskellige pladser viser samtidigt klart, at en meget stor mængde af metallerne må stamme fra nedpløjede bebyggelsesflader. På hovedparten af pladserne er fundene imidlertid spredt over store arealer, som vanskeligt lader sig tolke som sammenhængende bebyggelsesflader - heller ikke om man regner en gravplads som en del af bebyggelseskomplekset - Bejsebakken med det grundigt detektorafsøgte pløjelag og nærmest totaludgravede bebyggelse opbyder i den forbindelse en gylden mulighed for jævnnføring af fundspredningen i pløjelaget med de underliggende bopladsspor.

Som det fremgår af fundspredningskortet (fig. 7) er der gjort fund over størstedelen af markarealet ved Bejsebakken både på toppen og nedad den opdyrkede syd- og vestside. Bakketoppen, hvor selve bebyggelsen har ligget i jernalderen, er karakteriseret ved en markant koncentration af detektorfund, men også syd herfor 250-500 m nede ad bakkesiden ses en markant fundkoncentration..$^{17}$ 
Næsten hele det godt og vel $600.000 \mathrm{~m}^{2}$ store markareal er blevet prøvegravet, og ingen anlægsspor fra jernalderen er blevet fundet nedad bakkesiden. Regulære anlægsspor fremkom kun over et areal på omtrent $50.000 \mathrm{~m}^{2}$ knyttet til selve bakketoppen. Selv med forbehold for betydelige fejl omkring fundstedsangivelserne, som følge af den relativt unøjagtige metode anvendt af detektorfolkene i marken, kan der således ikke herske tvivl om, at en anseelig mængde af detektorfundene er fremkommet i områder uden underliggende bebyggelsesspor. ${ }^{18}$ Ligeledes udgøres undergrunden i en stor del af de anlægsfrie områder af kridt. Et underlag som almindeligvis er blevet undgået i bebyggelsesmæssig henseende.

Endelig kunne man umiddelbart frygte, at den intensive dyrkning af de fundrige marker efterhånden har forstyrret det geografiske fundbillede godt og grundigt på de enkelte pladser. Man forestiller sig uden større besvær en jernalderfibel på rejse gennem mulden forrest på et plovskær. En skræmmende og dog umiddelbart nærliggende tanke, som heldigvis øjensynligt afviger noget fra virkeligheden. Såvel nyere undersøgelser af gennempløjede skattefund fra både Gotland og Bornholm som matematisk funderede simuleringer af genstandes horisontale bevægelser i et pløjelag under dyrkning synes at pege

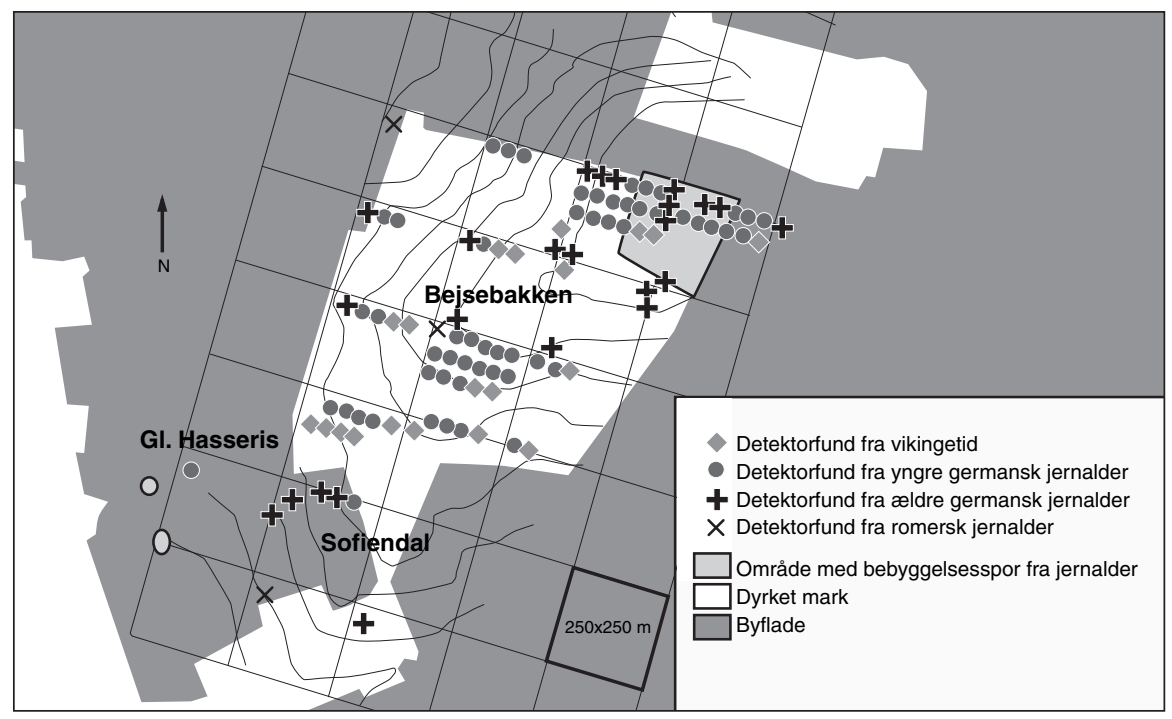

Fig. 7. Detektorfundenes spredning på Bejsebakken og Sofiendal/Gl. Hasseris i forhold til kendte bebyggelsespor fra jernalderen.

The distribution of detector finds on Bejsebakken and Sofiendal/Gammel Hasseris compared with known settlement traces from the Iron Age. 
på, at kun et fåtal af genstande flytter sig mere end 20-25 m fra oprindelsesstedet selv efter 50 års pløjning. ${ }^{19}$

Det synes altså evident, at fundspredningsmønstret på Bejsebakken ikke kan forklares med henvisning til hændelser i nyere tid, men formodentlig i store træk repræsenterer det oprindelige fundspredningsbillede fra jernalderen. I parentes skal det dog tilføjes, at terrænfaldet fra bakketoppen mod nordøst og ned mod Gl. Hasseris og Sofiendal $700 \mathrm{~m}$ mod syd og sydvest er på omkring $20 \mathrm{~m}$, og kan således have forårsaget en forskydning af fundene i denne retning. Der er dog næppe tale om forskydninger i en størrelsesorden, der kan have haft nogen afgørende indflydelse på ovenstående spredningsbillede. Det skulle i så fald have været forskydninger over flere hundrede meter.

Meget tyder således på, at en stor del af metallerne allerede i yngre jernalder er blevet spredt ud over et område betydeligt større end selve bebyggelsesfladen. Havde det drejet sig om enkelte fund uden for det bebyggede areal, kunne disse selvfølgelig have været tilfældigt tabte genstande. Der er imidlertid tale om over $50 \%$ af genstandene, hvilket selvsagt kræver en forklaring, og umiddelbart er mit bedste bud, at man simpelthen har anvendt bopladsaffald til gødskning af markerne op til selve bebyggelsen, hvorved metallerne sammen med andet småaffald er endt op til flere hundrede meter fra selve bopladsen.

Tager man udgangspunkt i gødskningsteorien bliver en mere indgående tolkning af detektorfundenes spredning ulig mere kompliceret end tilfældet var, hvis fundene lå, hvor de var tabt under brug. Netop det bebyggede område må i slige tilfælde forventes at være næsten umuligt at udskille alene på basis af de overfladefundne metaller. I denne sammenhæng bør det i øvrigt tilføjes, at ikke en gang fravær af metalfund i visse områder på de metalrige pladser kan forventes at afspejle arealer uden anlægsspor. I forbindelse med selv meget metalrige bebyggelseskomplekser er der på flere lokaliteter herhjemme iagttaget dele af bebyggelserne med meget få eller ingen metalfund. ${ }^{20}$ Endelig synes det klart, at såfremt metallernes geografiske spredning i virkeligheden for en stor del skyldes sekundær flytning af kulturmateriale i jordforbedringsøjemed, rejses endnu et afgørende spørgsmål. Hvad repræsenterer metallernes udbredelse så? Har man gødsket hele bebyggelsens tilknyttede markareal, i hvilket fald metalfundenes spredning jo så repræsenterer en bebyggelse med tilhørende intensivt dyrkede markarealer. Eller har man kun gødsket udvalgte marker? Eventuelt dem i bekvem afstand fra møddingen.

Endvidere kompliceres tolkningen af Bejsebakken-detektorfundenes spredning i forhold til bebyggelsessporene yderligere af det faktum, at der også på et plateau på bakkens sydvestside ved Gl. Hasseris i flere omgange er blevet regi- 
streret bebyggelsesspor fra yngre jernalder, hvorfor en del af metallerne også meget vel kan stamme fra aktiviteter udgået herfra. Når alt kommer til alt kan disse to bebyggede områder alligevel næppe tolkes uafhængigt af hinanden, men har givet opfyldt hver deres rolle i et lokalt bebyggelsessystem mere komplekst, end vi i dag formår at forklare. Et system som, såfremt der også findes bebyggelsesspor på Thulebakken, øjensynligt i hvert fald har rummet tre adskilte enheder. Her kunne man selvfølgelig fristes til at forklare dette tilsyneladende tætte bebyggelsesmønster som et resultat af gentagne landsbyflytninger og de enkelte påviste bebyggelsesflader som forskellige faser af samme bebyggelsesenhed. Selv med de store påvirkninger af materialespredningen, som foreslået ovenfor, skulle man dog i så tilfælde kunne forvente mere udtalte koncentrationer af materiale med ens datering. Hermed ikke sagt, at de enkelte enheder nødvendigvis ikke har flyttet sig i mindre målestok.

Betragter man fundspredningskortene fra de øvrige detektorpladser, som her er under behandling, ser man i næsten alle tilfælde et fundspredningsmønster meget lig det fra Bejsebakken. Hyppigt kan der iagttages en eller flere fundkoncentrationer, men som helhed er fundene spredt over store arealer. Thulebakken-pladsen er med sin udstrækning på lige godt og vel $200.000 \mathrm{~m}^{2}$ den mindste af disse, mens Nørholmlokaliteten med en udbredelse over et areal på omtrent $4.000 .000 \mathrm{~m}^{2}$ udgør den største. Kun Sebbersund bryder interessant nok dette mønster. Her er alle metalfundene uhyre koncentreret i forhold til de øvrige og findes inden for et område på kun ca. $16.000 \mathrm{~m}^{2}$. Dette fundspredningsbillede kunne selvfølgelig være et produkt af en håndfuld meget fokuserede detektorfolk, som kun har afsøgt de områder, som traditionelt har været fundgivende. Disse skulle dog i så fald have været ekstremt, ja nærmest usandsynligt fokuserede. Hertil kommer, at dette fundbillede bekræftes af folkene bag udgravningerne foretaget ved Sebbersund, og jævnfør disse udgøres dette metalførende areal øjensynlig primært af et handels- og håndværksområde. ${ }^{21}$

Denne markante forskel mellem Sebbersund og de øvrige pladser understreger klart førstnævntes særegne karakter, ligesom iagttagelsen også synes i god overensstemmelse med ovenstående betragtninger vedrørende årsagen til metallernes store spredning på de øvrige pladser. Netop Sebbersundpladsen synes således blottet for spor efter almindelig agrar bebyggelse og er tillige i så henseende topografisk set aldeles uhensigtsmæssigt placeret.

Omvendt taler såvel metallernes store spredning som pladsernes topografiske placering for, at alle de øvrige detektorpladser repræsenterer bebyggelser med en agrarproduktion. Ligeledes synes det umiddelbart med baggrund i Bejsebakken-eksemplet ikke usandsynligt, at flere om ikke alle de aktuelle 
fundrige bakkepartier i virkeligheden har rummet flere adskilte bebyggelsesenheder, som dog må formodes at have tjent hver deres rolle i et integreret lokalt bebyggelsessystem. På basis af det foreliggende fundmateriale, som jo for hovedpartens vedkommende alene udgøres af overfladefundne metalgenstande, er det dog ikke muligt med sikkerhed at udskille disse lokale enheder, ligesom rækkeevnen af detektorfundenes udsagnsværdi i det hele taget ikke kan strækkes til at omfatte mere detaljerede iagttagelser vedrørende de enkelte pladsers interne strukturer.

\section{Handel og håndværk}

Kun en beskeden del af aktiviteterne, som er foregået på pladserne, kan i sagens natur forventes afspejlet i danefæmaterialet og kun på de af lokaliteterne, hvor overfladeindsamlingen af metalgenstandene er suppleret med egentlige arkæologiske undersøgelser, kan et mere bredspektret billede af erhvervsmønstrene tegnes. Metallernes direkte udsagnsværdi begrænser sig primært til spørgsmål vedrørende selve metalhåndværket samt handel og import.

\section{Handel og import}

Betragter man detektormaterialet isoleret, er antallet af fund som med sikkerhed direkte kan relateres til enten metalforarbejdning, handels- og/eller importvirksomhed umiddelbart temmelig beskedent fra de her behandlede lokaliteter. Det kan selvfølgelig postuleres, at alle metallerne, givet det faktum, at råmaterialerne ikke forefindes lokalt, på sin vis afspejler importvirksomhed. Alene beviser forekomsten af disse dog ikke, at selve "handelen« har foregået her, ligeså lidt som deres tilstedeværelse kan bevises at være en følge af egentlig regulær handelsvirksomhed.

Håndgribelige indikatorer på handelsaktiviteter i form af vægte og vægtlodder optræder iøjnefaldende sjældent i detektormaterialet fra de aktuelle lokaliteter, og når de gør almindeligvis kun i enkeltstående eksemplarer. På Bejsebakken og Øland er der således fundet et enkelt vægtlod, mens Nørholmlokaliteten tegner sig for to. Sebbersund afviger også på dette punkt fra de øvrige, idet detektormaterialet herfra rummer ikke mindre end tre forhistoriske vægtlodder og to hele eller fragmenterede skålvægte. Dette skæve fundbillede forstærkes ydermere betydeligt, om man medregner udgravet materiale, idet det samlede antal vægtlodder fra Sebbersundpladsen eksempelvis overstiger 20, hvoraf enkelte dog skal dateres til den tidlige middelalder. Det endnu upublicerede fundmateriale fra udgravningen af Bejsebakken rummer i øvrigt også mindst yderligere et par vægtlodder. ${ }^{22}$ 
I alle tilfælde, hvor ovenstående vægtlodder og vægte fra detektorfundene i øvrigt lader sig datere nærmere, henføres disse ikke overraskende til vikingetiden.

Forhistoriske mønter er endnu mere sparsomt forekommende i detektormaterialet fra pladserne ved den østlige Limfjord, og er der foregået handelsaktiviteter, synes mønterne næppe at have spillet nogen afgørende rolle. Mønterne synes jæunt fordelt med to på Bejsebakken, to ved Sofiendal, to på Nørholm, tre ved Mellemholm og en enkelt fra henholdsvis Gjøl og Lindholm Høje. Hovedparten udgøres af romerske denarer fra de første århundreder e.Kr. og arabiske dirhemer fra 800-900-tallet. En enkelt mønt fra Karolingerriget slået i perioden 822-840 har dog sneget sig ind i Nørholm-materialet. Ydermere findes der blandt gravgaverne fra Lindholm Høje-gravpladsen en håndfuld arabiske mønter fra 900 -årene. ${ }^{23}$

Endelig optræder der i detektormaterialet fra Bejsebakken et par mulige stykker brudsølv og et enkelt stykke af lignende karakter fra Sebbersund. Sølv som formentlig efter vægt har fungeret som betalingsmiddel i vikingetiden.

Sidst, men ikke mindst kan de mange importgenstande på detektorpladserne jo også betragtes som indikator på handel eller udveksling. I den forbindelse bør man dog holde sig for øje, at disse selvfølgelig kan være nået frem til det østlige Limfjordsområde af mange forskellige årsager og på mange forskellige måder. Eksempelvis som følge af gavebytning, plyndring eller selvfølgelig handel både her og andetsteds. Importgenstandene bidrager dog med væsentlig information om hvilke områder, man har haft kontakt med gennem yngre jernalder. Igen er det imidlertid vanskeligt at vurdere karakteren af kontakten, og genstandene kan eksempelvis have passeret flere led for at nå det nordlige Jylland. Cirkulationstiden for bronzegenstande må dog generelt formodes at være betydeligt kortere, end tilfældet har været for ædelmetallerne, hvis lange levetid eksempelvis illustreres af de romerske denarer. ${ }^{24}$ Kortere cirkulationstid reducerer selvsagt chancen for, at bronzerne i almindelighed skulle have passeret en mængde led for at nå deres destination. Omvendt kan man dog langt fra afvise den mulighed, at nogle bronzer har cirkuleret længe efter endt primær brug, f.eks. i skrotform.

Betragter man fundlisterne over metalfundene fra de aktuelle Limfjordspladser, synes materialet fra ældre germanertid umiddelbart langt overvejende at bestå af hjemlige typer, og uden en nærmere gennemgang af dette materiale, som for hovedpartens vedkommende udgøres af korsformede fibler, er det vanskeligt at udpege nogen fremmede områder, med hvilke Limfjordsbefolkningen især synes at have plejet kontakt $\mathrm{i}$ ældre germanertid. Netop den korsformede fibel er vidt udbredt over det meste af Nordvesteuropa, og forskellene 
Fig 8. Importerede bronzer fra germansk jernalder. a: Næbfibel med nål fæstet i rør - Bejsebakken, b: Oval skålfibel Bejsebakken, c: Fibel med halvoval fodplade Sebbersund. Målestok $1: 2$

Imported bronzes from the Germanic Iron Age. a: Beak brooch with tube-mounted pin - Bejsebakken, b: Tortoise brooch - Bejsebakken, c: Brooch with spadeshaped foot - Sebbersund.

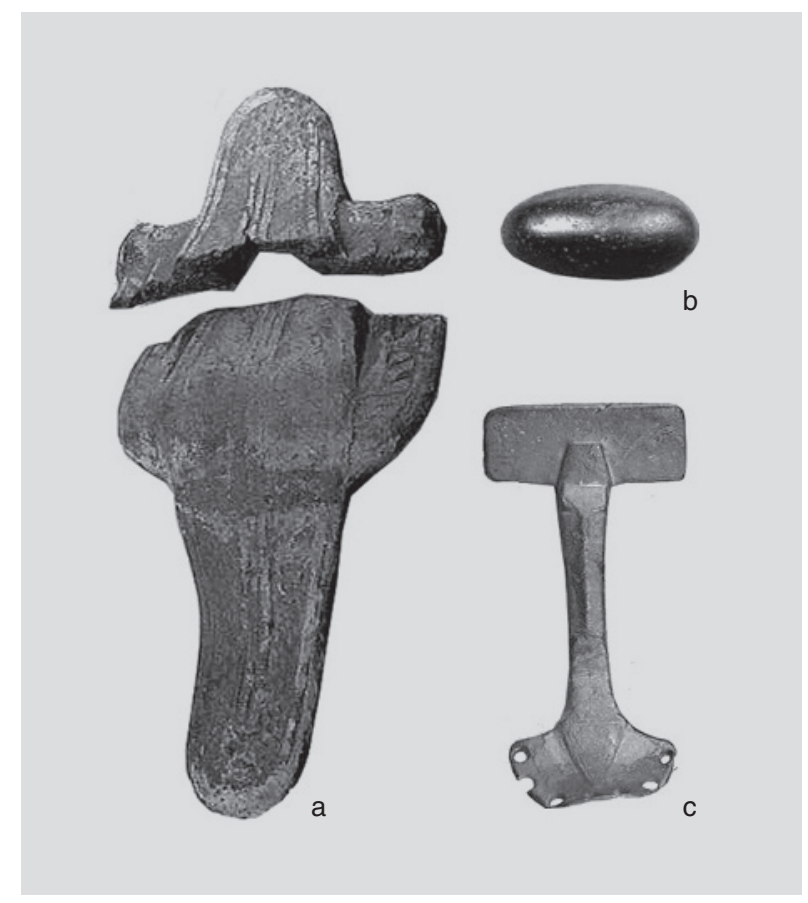

mellem fiblerne fra de enkelte regioner er i de fleste tilfælde relativt beskedne, ligesom nærmere studier af det danske materiale savnes. Generelt er indtrykket dog, at det fremmede islæt i materialet fra denne periode er yderst sparsomt. To fibler med spadeformet fod af norsk type, én fra Sebbersund (fig. 8c) og én fundet på Bejsebakken under de seneste udgravninger, bryder mønstret og skal muligvis ses som indikator på kontakt med nordmændene allerede i ældre germanertid. ${ }^{25}$

Også i materialet fra yngre germansk jernalder optræeder et par norske fibler, nemlig to runde skålfibler fundet på Bejsebakken og Postgården, og generelt er indtrykket, at der i detektormaterialet fra yngre germanertid forefindes lidt flere importgenstande. Endvidere synes der at være en mærkbar tendens til, at de fremmede metalgenstande i denne periode overvejende stammer fra det øvrige Skandinavien, og blandt importfundene fra yngre germanertid kan nævnes: Et par små ovale skålfibler fundet på henholdsvis Bejsebakken (fig. 8b) og Lindholm Høje, men oprindeligt hjemmehørende i Mälarregionen, ${ }^{26}$ et par store næbfibler fra henholdsvis Bejsebakken (fig. 8a) og Nørholm - begge med nålen fastgjort i rør, hvilket øjensynligt ikke er en nordjysk skik, men derimod har været fremherskende i det sydøstskandinaviske område bl.a. omfattende Øresundsregionen og Bornholm - samt et fragment af en forgyldt, dyrestilsdekoreret rygknapfibel af gotlandsk herkomst. 
Kontakten med de øvrige skandinaviske lande er i den efterfølgende periode, vikingetiden, ikke længere mulig at påvise i detektormaterialet, hvilket dog givetvis blot skal ses som et resultat af et udpræget ensartet smykketypeinventar over hovedparten af det skandinaviske område. Forekomsten af blandt andet klæbersten, skiffer og jern fra Norge på de udgravede pladser viser, at varetransporten herfra og til Limfjordsområdet langt fra svinder ind i vikingetiden, men snarere øges. Tilsyneladende i takt med at selve handelen synes at skifte karakter til øjensynligt at omfatte tiltagende mængder af »dagligvarer».

Blandt de vikingetidige importgenstande i detektormaterialet dominerer derimod genstande fra Nordvesteuropa herunder både den nordvestligste del af Kontinentet og De Britiske Øer.

De små cirkulære fibler ofte med korsmotiv udført i emaljeindlægninger udgør klart det talrigeste indslag i denne del af materialet. Lignende fibler kendes også fra Stentinget og Ejstrup i Vendsyssel, ligesom de efterhånden optræder i adskillige eksemplarer fra andre sydskandinaviske kystnære bebyggelser. Bl.a. er flere fundet på detektorpladser i Roskildeområdet og ved Uppåkra i Skåne. På Limfjordspladserne er emaljefibler fundet i enkelte eksemplarer på Postgården, Bejsebakken, Lindholm Høje og på Gjøl, mens Nørholm tegner sig for hele fire eksemplarer og Sebbersund for fem, hvoraf to stammer fra udgravningen af dele af pladsen. ${ }^{27}$

Gruppen af små cirkulære fibler omfatter også en lille håndfuld hjulformede fibler, som er små cirkulære fibler med seks huller langs randen. Disse optræder indtil videre i seks eksemplarer jæunt fordelt på de store detektorpladser, og de kendes i dansk regi bl.a. også fra Ribeegnen og Stentinget. Typen er dog også bl.a. fundet i flere eksemplarer i Schouwen ved Rhinens munding, og det synes på den baggrund oplagt at antage, at både en del af emaljefiblerne og hjulfiblerne afspejler en direkte kontakt ad søvejen mellem Limfjorden og det frisiske område i vikingetiden. ${ }^{28}$ Betydningen af en sådan sydgående sejlrute har ellers på bekostning af fokusering på den nordgående rute til Norge og den vestgående mod De Britiske Øer hidtil været nedtonet i nyere litteratur. ${ }^{29}$

Blandt de vikingetidige importfund skal en smuk emaljebelagt fingerring fundet på Nørholm endvidere fremhæves (fig. 9b). Ringen er hele vejen rundt dækket af et velbevaret geometrisk mønster i emalje bestående af rækker af gule L-er. Mønstret er hjemmehørende i den irske metalkunsttradition og går bl.a. igen på flere fornemme bronzearbejder fundet i rige norske vikingetidsgrave. ${ }^{30}$ Også en enkelt af de ovenstående korsemaljefibler fra Sebbersund kan i øvrigt knyttes til det irske bronzestøbermiljø (fig. 9c). ${ }^{31}$

De vestgående forbindelser ses ydermere afspejlet $i$ en gruppe af engelskinspirerede metaller knyttet til rideudstyr, der i de senere år har nydt øget op- 
mærksomhed. Engelskinspireret rideudstyr fra sen vikingetid er som følge heraf efterhånden blevet påvist spredt over store dele af Sydskandinavien, men med en mærkbar koncentration i Limfjordsområdet, og flere af de her behandlede pladser har da også leveret stykker tilhørende denne kategori. ${ }^{32}$

Endelig optræder der blandt detektorfundene udover de fåtallige arabiske mønter enkelte andre genstande af orientalsk præg. Om disse enkelte genstandes forekomst i Limfjordsområdet er en følge af direkte, langtrækkende forbindelser østover eller blot afspejler kontakt med det østsvenske område, hvor den orientalske import optræder mere massivt i vikingetiden, skal ikke søges afklaret i denne sammenhæng. ${ }^{33}$ Dette orientalsk inspirerede materiale omfatter bl.a. et fint lille bæeltebeslag af bronze dateret til sen vikingetid fundet ved Nørholm (fig. 9a), til hvilket der bl.a. findes et beslægtet stykke fundet i Sverige. ${ }^{34}$ Endvidere findes i detektormaterialet fra Sebbersund et lille hjerteformet, orientalsk beslag, og et lignende stykke optræder desuden blandt udgravningsfundene fra samme lokalitet. Hertil kommer, at der fra Ørsnes`gravning på Bejsebakken foreligger et orientalsk remspænde, og endelig optræder der i fundmaterialet fra Lindholm Høje en karneolperle, hvis oprindelsessted øjen-

Fig. 9. Importerede bronzer fra vikingetid. a: Orientalsk rembeslag - Nørholm, b: Fingerring med emaljeindlægninger - Nørholm, c:

Korsemaljefibel - Sebbersund.

Målestok 1:1.

Imported bronzes from the Viking Age. a: Oriental strap mount, - Nørholm, b: Enamelled ring - Nørholm, c: Enamelled cross brooch Sebbersund.

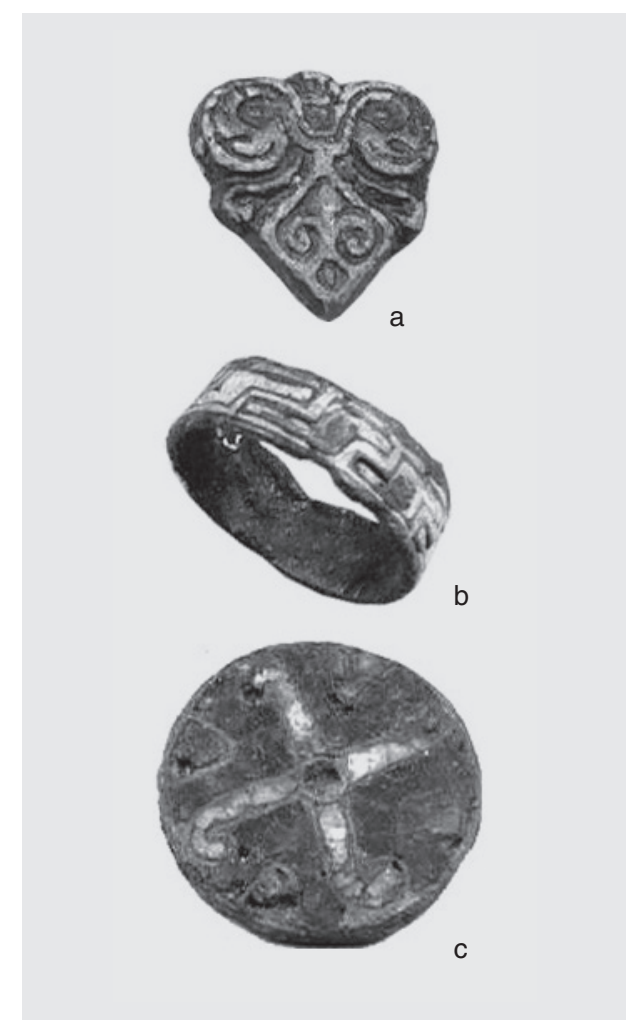


synligt også skal søges langt mod øst. Karneolforekomster findes bl.a. i Yemen, Indien og Kaukasusområdet. ${ }^{35}$

Generelt efterlader det forhåndenværende materiale således et meget groft og givetvis i mange henseender aldeles ufuldstændigt billede af handelsaktiviterne knyttet til de store detektorpladser ved den østlige Limfjord i yngre jernalder. Alle de mere regulære indikatorer på handel i form af vægte og vægtlodder er, når en nærmere datering foreligger, dateret til vikingetiden, og disse optræder kun, når man ser bort fra Sebbersund, ganske sporadisk. Mønter og ædelmetaller optræder om muligt i endnu mindre mængder. Fundet af en række importerede metaller såvel som flere andre ikke-metalliske varetyper vidner dog om et vidt udbredt kontaktnet i yngre jernalder, og de højtliggende bebyggelser kan næppe forstås uden reference til en eller anden form for handelsvirksomhed.

\section{Håndværksaktiviter}

Detektormaterialets bidrag til belysning af de håndværksmæssige aktiviteter, som er foregået på fundpladserne, er som nævnt yderst beskedent og begrænser sig udelukkende til vidnesbyrd om selve metalforarbejdningsarbejdet. Herunder næsten udelukkende bronzeforarbejdningen. Havde materialet også omfattet jerngenstandene, ville flere håndværk givetvis være repræsenteret.

Eneste regulære indicier på metalforarbejning i detektormaterialet er således en brakteatmatrice og lidt bladguld fra Postgården, en mulig fejlstøbning fra Nørholm, en enkelt smelteklump af guld fra Bejsebakken, bronzebarrer, guldog sølvsmelteklumper samt en blymodel til urnesfibler fra Sebbersund og et par bronze-smelteklumper fra Lindholm Høje. Hvorvidt sidstnævnte imidlertid er brændte gravgaver eller regulære spor efter bronzestøberi er usikkert. Endelig er det tidligere blevet påpeget, at der i Bejsebakken-materialet optræder tre fuglefibler af så stor indbyrdes lighed, at de må tolkes som produceret efter samme model eller i samme form. Umiddelbart også et stærkt indicium på at bronzestøberen har virket på denne lokalitet. ${ }^{36}$

Alt $i$ alt et uhyre spinkelt og givetvis aldeles urepræsentativt materiale er der tale om, både i relation til det samlede spekter af håndværksaktiviteter, men øjensynligt også i relation til arbejdet med ædelmetaller og bronzer. I forbindelse med metalhåndværkene lider materialet bl.a. frygteligt under det faktum, at kun danefæmateriale er registreret. Kun i sjældne og overvejende ældre tilfælde er bronzeskrot og lignende blevet registreret. Det er da også et faktum, at på alle de af lokaliteterne, hvor der har været foretaget større udgravninger, er der fundet forskellige spor efter bronzeforarbejdning af varierende art, dog ikke i tilfældet Postgården. Fra Bejsebakken og Lindholm Høje foreligger enkelte 
bronzestøbeforme, og på Sebbersundpladsen er bronzestøberiet udover ovennævnte repræsenteret ved et par støbekegler, esseslagger og en bronzepatrice til produktion af urnesfibler. Patricen har været anvendt til fabrikation af urnesfibler tilhørende Aalborg-gruppen - en gruppe urnesfibler uden dyreslyng - hvis absolutte hovedudbredelsesområde begrænser sig til Limfjordsområdet og specielt til fjordsystemets østende. ${ }^{37}$ Endelig er der ved Sebbersund også under udgravningerne fundet enkelte spor efter forarbejdning af guld og sølv i form af et par småslagger med spor af guld samt endnu en smeltedråbe af sølv.

Betragter man endvidere helt overordnet det rige fundmateriale fra regionen, forekommer det efterhånden sandsynligt, at det østlige Limfjordsområde i store dele af yngre jernalder har været hjemsted for et foretagsomt og innovativt bronzestøbermiljø. Specielt det store materiale fra yngre germanertid synes at indikere dette. Flere af de klassiske fibeltyper såsom f.eks. ovale og rektangulære pladefibler er således markant koncentreret i Limfjordsområdet. Hertil kommer, at enkelte specielle variationer af disse, som feks. de ovale og rektangulære fibler i gennembrudt arbejde og de rektangulære fibler af jern, indtil videre næsten udelukkende forekommer i Limfjordsområdet og hyppigst på de store østlige detektorpladser. Endelig har Ørsnes bl.a. også peget på det østlige Limfjordsområde som muligt oprindelsessted for dyrestil D. ${ }^{38}$ Alt sammen blot indicier på et aktivt bronzestøbermiljø. Materialet er dog for yngre germanertid efterhånden så stort, at nøjere studier af dette muligvis vil kunne bidrage til en nærmere påvisning af en eller flere sådanne mindre værkstedskredse.

Vurderet ud fra det nuværende fundmateriale ser guld- og sølvsmedehåndværket i modsætning til bronzestøberhåndværket absolut ikke ud til at have været en almindeligt forekommende aktivitet. Selv med forbehold overfor, at meget uregistreret ædelmetal kan være fremkommet på de implicerede marker som følge af bøndernes århundreder lange, intensive dyrkning af disse, synes mængden af fundne ædelmetaller uhyre lille på de aktuelle lokaliteter, og specielt mindre stykker produktionsaffald skulle man umiddelbart forvente i større tal, såfremt sølv- og guldsmedehåndværket havde været et fast element på bopladserne. Men antallet af fortinnede og forgyldte bronzer synes dog at pege i retning af, at dette har været et relativt almindeligt fænomen i området, og arbejdet hermed har velsagtens været mestret og foretaget af bronzestøberen.

Studerer man fundmaterialet fra udgravningerne pa flere af de aktuelle pladser, fremkommer imidlertid et helt andet og langt mere nuanceret billede af håndværksaktiviteterne bedrevet på disse lokaliteter. Bedst repræsenteret er tekstilfremstillingen, som på mange måder synes at dominere fundbilledet. Alle pladserne er kendetegnet ved forekomsten af et stort antal grubehuse, hvis funktion i mange tilfælde ikke lader sig entydigt afklare. Når dette imidlertid 


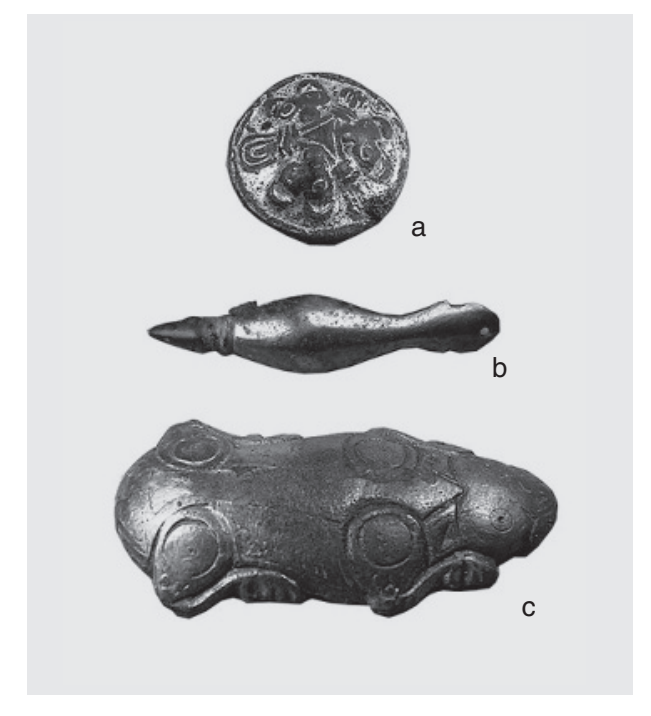

Fig. 10. Fortinnede og forgyldte bronzer. a: Cirkulær fibel - Humlebakken, b: Fuglefibel - Nørholm, c: Dyreformet skålfibel - Mellemholm. Målestok 1:2.

Tin-plated and gilded bronzes. a: Circular brooch - Humlebakken, b: Bird brooch - Nørholm, c: Animal-shaped brooch - Mellemholm

er muligt, synes tekstilfremstillingen næsten eneherskende, hvilket hyppigst kommer til udtryk gennem fund af tenvægte samt brændte og ubrændte vævevægte liggende på husgulvene. På Bejsebakken og Sebbersund synes antallet af grubehuse, som begge steder tilsyneladende tæller flere hundrede, at signalere en tekstilproduktion af et omfang, som klart overstiger, hvad der umiddelbart kan forventes forbrugt lokalt i selve bebyggelsen.

Også smedehåndværket synes ikke overraskende at have været vidt udbredt og findes bl.a. repræsenteret på Bejsebakken, Lindholm Høje og Sebbersund i form af jernslagger fra fylden i anlæggene eller knyttet til kulturlag på pladserne. Endvidere optræder der jernbarrer i fundmaterialet fra samme lokaliteter. Hertil kommer, at udgravningsmaterialet fra samme tre pladser ydermere bl.a. indeholder en mængde jernredskaber, som vidner om håndværk omfattende bl.a. bearbejdning af træ, læder og ben.

Alt i alt kommer detektormaterialet således til kort, når omfanget og karakteren af håndværksaktiviteterne ønskes belyst. Generelt fornemmer man dog på baggrund af de udgravede dele af flere af pladserne et billede præget af en betydelig specialisering især i forbindelse med tekstilproduktionen.

\section{Regional fundspredning - overordnet bebyggelsesmønster}

Kortlægges det resterende fundmateriale fra germansk jernalder og vikingetid registreret i regionen, forstår man straks omfanget af detektorfolkets betydning for studiet af periodens bebyggelsesmønstre. Detektorerkendte lokaliteter ud- 
gør hele $43 \%$ af alle registreringer, og netop på den baggrund kommer det generelle detektorafsøgningsniveau i regionen til at stå centralt under vurderingen af det overordnede fundbilledes repræsentativitet.

Langt den overvejende del af de øvrige detektorfund fra regionen udgøres af spredte enkeltfundne genstande. Materialet rummer dog også fem andre detektorpladser med flere fund fra yngre jernalder (fig.11). Disse er alle kendetegnet ved en placering i baglandet bag de fundrige bakkepartier langs Limfjordskysten. De er stadig knyttet til morænebakkerne, men nu til de bakker som ligger i manden række». Til trods for dette synes de umiddelbart stadig at have en hvis orientering mod fjorden eller måske mod de store pladser på bakkeøerne langs denne, for alle er lokaliseret på overgangen mellem de højereliggende områder og de lavtliggende engarealer, som adskiller indlandet fra de kystnære bakkeøer med de rige detektorlokaliteter.

Suppleres detektorfundene med det resterende fundmateriale fra regionen, fremkommer en langt bredere geografisk fordeling af fundene. Store dele af området er dog endnu meget tyndt besat, om man ønsker at studere enkeltperioder i yngre jernalder. Det samlede antal registreringer tegner således endnu et meget grovkornet billede af bebyggelsen omkring fjorden, men et par generelle tendenser springer dog i øjnene.

For det første syntes intet at kunne rokke ved det faktum, at området generelt må have været ganske tæt bebygget i yngre jernalder. Kun de lavtliggende, fugtige engarealer i de store ådale og på de hævede marine arealer synes uden bebyggelse. Muligvis er bebyggelsestætheden dog allerede en 5-10 km inde i landet begyndt at aftage, om end undersøgelsesniveauet endnu er for ringe til at verificere dette. Som fundbilledet tegner sig p.t., synes ikke kun de kystnære bakkeøer tæt bebygget, men også de kystvendte dele af bakkelandskabet $\mathrm{i}$ indlandet bag disse.

For det andet synes bebyggelsessporene fra yngre jernalder at have en hvis tendens til at være beliggende nær overgangen fra de højtliggende bakkelandskaber til de lavtliggende engarealer. Nok findes alle bebyggelsesindikatorerne oppe i bakkerne, men ser man bort fra offer/depotfundene, findes kun to fund mere end $1,5 \mathrm{~km}$ fra de fugtigere engarealer.

Endnu er tegningen af det samlede fundbillede dog forbundet med betydelige problemer. Specielt detektorfundenes afgørende aftryk på fundspredningskortet lader forvente, at billedet i nogen grad er skævvredet som følge af uens afsøgningsniveau i forskellige områder. Man fornemmer dog af detektorfundenes spredning, at $\mathrm{i}$ hvert fald toppen af de fjordnære bakkeøer og bakketoppene i det nærmeste bagland er relativt velundersøgte i detektormæssig henseende, hvorfor fundbilledet, præget af de særligt rige pladser langs fjorden i kontrast 


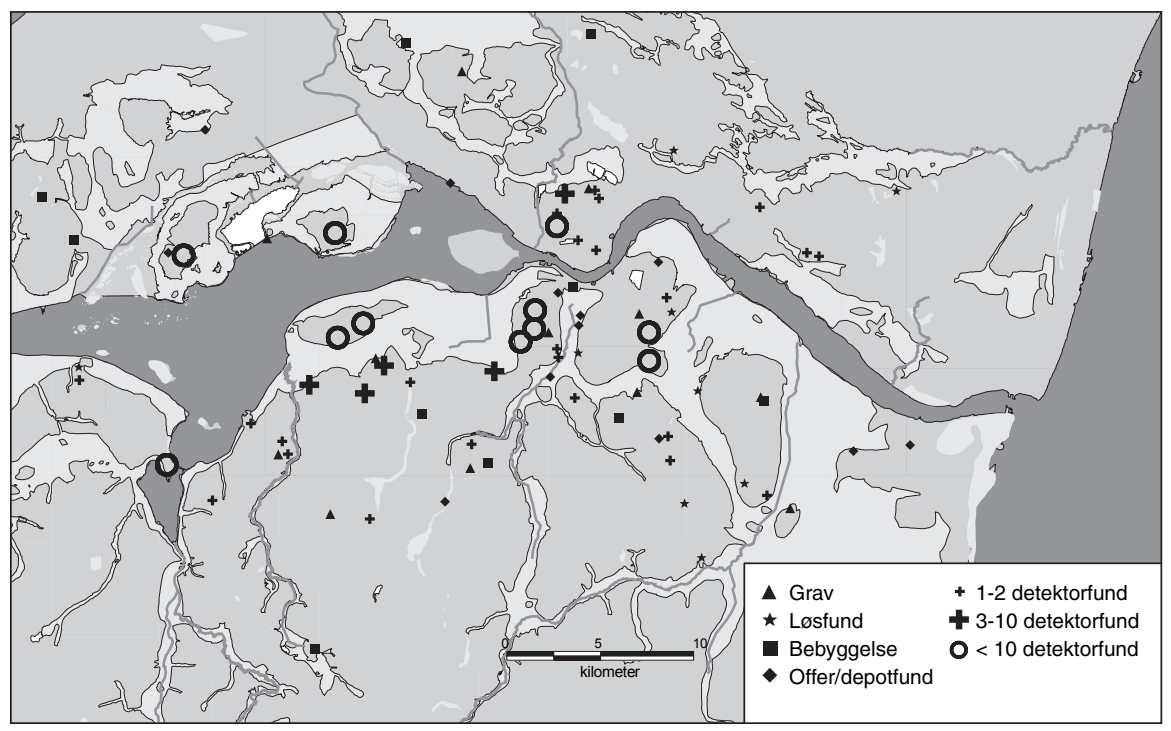

Fig. 11. Alle registrerede fund fra yngre jernalder omkring den østlige Limfjord.

All recorded finds from the Late Iron Age on the Eastern Limfjord.

til mindre velforsynede pladser i baglandet, må forventes at være rimeligt repræsentativt. Det relativt beskedne antal registreringer fra selve kystzonen synes imidlertid iøjnefaldende og hænger givetvis sammen med en ringe detektorafsøgningsindsats i disse områder. Marker under opdyrkning er således detektorfolkenes foretrukne terræn, og hyppigt bliver netop de lavtliggende strandenge benyttet til græsningsarealer og bliver derfor sjældent pløjet.

På baggrund af det relativt gode afsøgningsniveau på toppen af de store bakkeøer langs fjorden fremstår manglen af detektorfund fra Sejlflodbakken i øvrigt forbavsende og nærmest uforklarlig. Lokaliteten er jo almindeligt kendt fra udgravningen af jernaldergravplads og bebyggelse tilbage i 80'erne, og man skulle forvente, at området herefter ville have virket som en magnet på detektorfolkene. ${ }^{39}$

\section{Tolkning af detektorpladserne}

Som foreslået ovenfor kan der, med udgangspunkt i metalfundenes spredning og detektorfundspladsernes generelle topografiske placering, argumenteres for at betragte hovedparten af de aktuelle Limfjordspladser som landbebyggelser, hvor den agrare produktion synes at have været af stor betydning. Omvendt 
vidner den skæve fordeling af metalfundene og den generelt forhøjede cirkulation af metalgenstande på de her behandlede pladser om aktiviteter, som ligger udover det, man almindeligvis kan forvente på en agrar jernalderbebyggelse.

Søger man imidlertid i materialet efter specifikke udtryk for udøvelsen af centrale funktioner på de enkelte pladser, synes resultatet yderst spinkelt. Nok forefindes en del genstande repræsenterende metalkunst i høj klasse i hvert fald fra yngre germansk jernalder og vikingetid, men generelt fremstår de få fund af ædelmetaller dog ejendommelig. Fund af bl.a. fine importvarer, mønter i større antal, brakteater og guldgubber mangler næsten helt på bebyggelserne ved Limfjorden, og netop sådanne genstande tillægges jo ellers ofte stor tolkningsmæssig betydning i forbindelse med de store detektorpladser i det øvrige Sydskandinavien. Almindeligvis ses disse genstande som udtryk for tilstedeværelsen af personer med politisk, økonomisk og religiøs magt. ${ }^{40}$ Ydermere synes detektormaterialet også at savne vidnesbyrd om tilstedeværelsen af militær magt på pladserne. Enkelte beslag og fragmenter som eksempelvis et muligt hjelmfragment fra Bejsebakken kunne med lidt god vilje ses som tegn herpå.

Generelt fremstår sporene efter miljøer eller enkeltpersoner med militær, politisk og religiøs magt således uhyre svage i detektormaterialet fra de her behandlede lokaliteter, og man spørger sig selv, om ikke det blot er et udtryk for manglende mulighed for at erkende dette i detektormaterialet. Studeres udgravningsresultater fra undersøgelser foretaget på flere af pladserne, findes enkelte tegn på tilstedeværelsen af centrale funktioner. Her tænkes især på forekomsten af et særligt langhus med et unormalt stort fundmateriale omfattende bl.a. frankisk glas og ikke mindste pile-, spyd- og lansespidser fundet på Bejsebakken, ligesom man selvfølgelig heller ikke kommer udenom, at den træbyggede kirke ved Sebbersund repræsenterer en central religiøs funktion. For sidstnævntes vedkommende kan der ikke herske tvivl om pladsens særstatus. Denne plads afviger dog tydeligvis markant fra de øvrige ikke blot funktionsmæssigt men også i nogen grad dateringsmæssigt og skal derfor efterfølgende behandles særskilt.

Hvad angår langhuset på Bejsebakken kan der næppe være tvivl om, at de personer, som har haft til huse her, har haft særlig status, og sammen med de mange detektorfund fra bakken giver disse klart et indtryk af, at pladsen på visse områder må have haft centralpladskarakter. En nærmere afdækning af karakteren og omfanget af den eller de centrale funktioner er anderledes problematisk. Man kan selvfølgelig argumentere for, at ovennævnte langhus synes at indikere tilstedeværelsen af personer med politisk, religiøs og militær magt. Langhus såvel som detektormateriale blegner dog noget ved siden af halbygningerne og ædelmetalfundene fra det sydøstlige Danmark, ligesom det på 
grundlag af det nuværende undersøgelsesniveau på alle de øvrige detektorpladser langt fra kan afvises, at lignende bygninger optræder på de andre bakkeøer langs den østlige Limfjord. Generelt synes indtrykket således at være, at har Bejsebakken haft central funktion i disse henseender, kan der meget vel have været tale om funktioner på lokalt niveau. Når alt kommer til alt, synes Bejsebakkens primære centrale funktion at være af økonomisk art i lighed med næsten alle de her behandlede lokaliteter. Fælles for alle er den centrale placering ved områdets vigtigste transportvej "Limfjorden«, og dette sammenfald kan som tidligere postuleret næppe forklares uden henvisning til handelsvirksomhed. En handel som formentlig er gået hånd i hånd med en øget specialisering og koncentrering af visse håndværk på pladserne.

I forbindelse med den geografiske udstrækning af denne centrale rolle er det selvfølgelig fristende at tilskrive Bejsebakken regional betydning pga. det markant største detektormateriale. Indtil videre adskiller denne lokalitet sig dog primært kun fra de øvrige ved vidnesbyrd om større cirkulation af metalgenstande, og selv på det punkt gør nabobakkeøen Nørholm, om fundtilvæksten fortsætter som hidtil, snart Bejsebakken rangen stridig. Forskellene mellem disse pladser er således formentlig ikke af funktionel art, men skal måske snarere søges i variation i de enkelte bebyggelsers evne til at tiltrække sig handelen.

Når dette er sagt, skal det dog tilføjes, at Bejsebakken næppe kan betragtes uafhængigt af udviklingen i området ved Østerås udmunding i Limfjorden umiddelbart nedenfor bakken. Her i Aalborgs centrum er der således under resterne af byens middelalderlige bygninger fundet spor efter en ældre bebyggelse, som indtil videre kan dateres helt tilbage til omkring begyndelsen af 800-tallet. I begyndelsen synes denne at have haft et agrart fokus, men allerede i 900-årene erstattes landbebyggelsen øjensynligt af en handels- og værkstedsplads. Hertil kommer, at kongen i sen vikingetid lod slå mønt i Aalborg, hvilket må betragtes som et klart signal om byens centrale stilling og kongemagtens store interesser i området på daværende tidspunkt. ${ }^{41}$ Der kan således på den baggrund ikke herske tvivl om, at Aalborg allerede engang i løbet af vikingetiden erhverver sig rollen som regionens absolutte hovedcenter.

Omtrent samtidig med at bebyggelsen ved åmundingen skifter karakter fra agrar til handelsorienteret, synes cirkulationen af metaller oppe på Bejsebakken at reduceres, og det er vel sandsynligt, at aktiviteterne, som før fandt sted på bakkens top, flyttes ned til åmundingen. Ja, faktisk savnes spor af bebyggelse fra i hvert fald den sene vikingetid på den næsten totaltudgravede bakketop, og måske sker der en regulær udflytning fra bakketoppen? Detektormaterialet herfra viser dog fortsat spor efter aktivitet i den sene vikingetid og middelalder. Muligvis repræsenterer de yngre fund således blot gødning udført fra byen. 
I lyset af den ovenfor beskrevne udvikling fremstår Nørholmlokaliteten i ørigt som noget af et paradoks. For netop som regionens hovedcenter synes at forme sig, rent fysisk manifesteret gennem bydannelsen omkring Østeråmundingen, øges cirkulationen af metaller her kun $10 \mathrm{~km}$ længere mod vest. Det er dog ikke det eneste sted, hvor aktivitetsniveauet accelererer i vikingetiden. Også ved Sebbersund synes dette at være tilfældet. Trods centerdannelse har man tilsyneladende ikke formået at oprette en total styring af handelen, og i hvert fald nogle af bebyggelserne på holmene ved fjorden har således formået at bibeholde centrale funktioner til trods for en yderst begrænset afstand til centret ved Aalborg.

Sebbersundpladsen afviger på flere punkter afgørende fra de øvrige detektorpladser. Den lavtliggende, kystnære placering, fraværet af tegn på agrarøkonomi samt tilstedeværelsen af det tidlige kirkebyggeri efterlader et indtryk af en plads af helt anden karakter end disse. Hertil kommer, at pladsen modsat de øvrige at dømme udfra detektorfundene kun har været sporadisk benyttet gennem store dele af germansk jernalder for først at toppe aktivitetsmæssigt $\mathrm{i}$ 1000-tallet og herefter ophøre ret brat i starten af 1100-tallet - formentlig som følge af tilsandingen af Limfjordens vest- og nordvendte mundinger. Af udgraverne tolkes pladsen som en lokal handelsplads i germansk jernalder, hvis betydning dog tiltager i begyndelsen af 700-tallet, i forbindelse med hvilket denne efterhånden opnår regional status. ${ }^{42}$ Alt tyder da også på, at pladsen ved Sebbersund har haft en central funktion som handelsplads. Grundet det generelt dårlige undersøgelsesniveau i de kystnære områder langs Limfjorden kan der dog rejses tvivl om, hvorvidt Sebbersundpladsen har været én af ganske få lignende pladser i det østlige Limfjordsområde i yngre jernalder. Den decentrale struktur med mange tætliggende bebyggelser af ensartet karakter, som indikeret af detektormaterialet, synes at afspejle fri adgang til handelen. Havde restriktioner koncentreret handlen på enkelte pladser i regionen, skulle man vel umiddelbart forvente en mere ujævnt fordelt metalcirkulation indbefattende enkelte meget rige pladser med kontrollen over handlen.

\section{Udviklingen i den østlige Limfjordsregion i bredere perspektiv}

Allerede i ældre jernalder synes de kystnære områder omkring den østlige Limfjord ganske tæt bebygget, og hovedparten af bakkeøerne rummer bebyggelser, som tillige synes at have medført øget cirkulation af metalgenstande i forhold til bebyggelserne længere inde i landet. Ikke nogen voldsom forskel, men dog mærkbar især for yngre romertids vedkommende. Godt nok synes 
bebyggelsesenhederne mindre og antallet af disse større, men grundkonturer til bebyggelsesbilledet i yngre jernalder synes til stede allerede i ældre jernalder. ${ }^{43}$ Kanske fjorden ikke kun har været en vigtig transportvej, men også har udgjort det ekstra ressourcegrundlag, som tidligt har hævet de kystnære bebyggelser lidt over de øvrige. Bebyggelser som med en solid basisøkonomi og et ressourcestærkt bagland har kunnet danne grobund for en lokal elite, hvis position blev styrket gennem bl.a. kontakten med andre ligestillede og udvekslingen af prestigevarer med disse.

Fjorden har utvivlsomt i dette spil haft en uhyre væsentlig rolle som kommunikationsvej, og selvom det er vanskeligt at vurdere nøjagtigt, er der heller ingen tvivl om, at fjordens betydning som transportvej øges op gennem yngre jernalder i takt med den stigende handel. Mod slutningen af yngre germansk jernalder optræder de første importerede dagligvarer på danske bopladser, og skibstrafikkens afgørende rolle kan fra det tidspunkt ikke bestrides. Hertil kommer, at man allerede i tidlig vikingetid kan iagttage fremkomsten af egentlige fragtskibe og en øgning af disses lasteevne op gennem vikingetiden. ${ }^{44}$

At Limfjorden lokalt set har udgjort en vigtig og hyppigt foretrukken kommunikationsvej synes naturligt, regionens særegne topografi taget i betragtning. De mange brede, fugtige engarealer og store ådale, som adskilte de beboede bakkeøer, har givetvis virket fremmende for den lokale skibsfart. Det kan imidlertid diskuteres, hvor stor betydning man skal tillægge Limfjorden som transportvej i overregionalt perspektiv i yngre jernalder. Der synes dog efterhånden at være belæg for at tilskrive den relativt stor betydning - især for skibstrafikken mellem Norge og det Sydskandinaviske område og forbindelserne mod vest til De Britiske Øer. ${ }^{45}$ Dette mønster understøttes af detektormaterialet fra bebyggelserne på de kystnære bakkeøer. Dog optræder der efterhånden også en del vikingetidige fund, som knytter Limfjordsområdet til det nordvesteuropæiske kontinent i denne periode.

At netop turen gennem Limfjorden hyppigt er blevet foretrukket frem for en rute nord om Skagen, skyldes formentlig to faktorer, nemlig de vanskelige besejlingsforhold omkring selve Grenen og ikke mindst det faktum, at vejen gennem Limfjorden simpelthen var kortere.

Det er derfor næppe tilfældigt, at Aggersborg, den største af landets »Trelleborge«, i slutningen af 900-tallet ikke alene bliver anlagt på den centrale Limfjords smalleste sted, men også umiddelbart øst for den nordgående Sløjenkanal. En strategisk placering som uden tvivl har haft sigte på ikke kun at kontrollere den nord-syd-gående landtrafik, men også har muliggjort en overvågning af al skibsfart gennem fjorden. 
Hertil kommer ydermere, at Limfjorden optræder i et par skriftlige kilder, hvor fjorden tilsyneladende i den sene vikingetid besejles af først Knud den Store og senere af den norske konge Harald Sigurdarsson, ligesom den også i 1085 skulle have dannet base for en samling af den kongelige flåde umiddelbart før en planlagt tur mod England. ${ }^{46}$

Fremkomsten af de rige bebyggelser langs Limfjordens østlige forløb fremstår på den baggrund ikke overraskende og synes i øvrigt i fin overensstemmelse med hovedtrækkene i samfundsudviklingen i Sydskandinavien. Vurderet ud fra det nuværende fundmateriale ser det imidlertid ikke ud til, at den hierarkiske samfundsstruktur udvikles i samme tempo i det østlige Limfjordsområde som i det sydøstlige Danmark og Skåne, hvor en langt mere centraliseret bebyggelsesstruktur og store koncentrationer af rigdomme på enkelte bebyggelser kan iagttages. En struktureringsproces som for Gudmes vedkommende allerede tager sin begyndelse i 3.-4. århundrede.

Ideen om en sådan forsinket centraliseringsproces i det nordjyske er da også allerede tidligere blevet fremsat, men denne rejser imidlertid en række nye spørgsmål. ${ }^{47}$ Centralt blandt disse synes at være problemstillingen omkring fastlæggelsen af tidspunkterne for skiftet til en mere hierarkisk samfundsstruktur og fremkomsten af centralpladser, hvis centrale funktioner har tjent et større område i den østlige Limfjordsregion.

Udviklingen op gennem yngre germansk jernalder kommer på baggrund af ovenstående efterhånden til at stå temmelig central for forståelsen af den generelle samfundsudvikling i regionen. Vi har et rimeligt velfunderet billede af et samfund med en decentraliseret bebyggelsesstruktur og en svagt udviklet ledelse i ældre germanertid og i vikingetid en lignende bebyggelsesmønstring dog efterhånden med et klart hovedcenter i Aalborg og et ved Aggersund og med vidnesbyrd om tiltagende kongelige interesser i området op gennem perioden. Som fundmaterialet ser ud på nuværende tidspunkt, er vurderingen af centraliseringsprocessens tempo i mine øjne indtil videre et temperamentsspørgsmål. Der kan argumenteres for at se Bejsebakken-bopladsen som regionalt center i den østlige Limfjordsregion i yngre germanertid. Tegnene på tilstedeværelsen af en elite med større politisk, religiøs og militær magt er dog spinkle, og der sker tilsyneladende generelt et markant opsving i metalcirkulationen i flere af de kystnære bebyggelser i regionen i dette tidsrum, og disse må fortsat have besiddet i hvert fald visse centrale roller. Fra og med det 9. århundrede - måske endnu tidligere - må man dog regne med, at hele Jylland og i hvert fald de nærmeste øer har udgjort grundstammen i det danske rige ${ }^{48}$, og har den hierarkiske samfundsstruktur før dette tidspunkt ikke været særlig udbygget i Nordjylland, er denne jo automatisk blevet en realitet i det 
øjeblik, området bliver underlagt en konge. Lader man fantasien tage styringen for en stund, kan man dog let forstille sig de konflikter, der kan opstå i forbindelse med indførelse af en ny, markant hierarkisk samfundsstruktur i et område, som hidtil har været bygget op omkring en række principielt ligestillede lokale stormænd. Måske har opførelsen af ringborgen ved Aggersborg centralt i Limfjordsområdet ikke blot haft til formål at forsvare landet mod en udefra kommende fjende og kontrollere skibstrafikken gennem fjorden, men har også kunnet stille kongemagtens behov for en understregning af herredømmet i et område, som måske endnu selv efter næsten et par århundreder under tronen ikke var beboet af lutter royale støtter. Det faktum, at en eksisterende bebyggelse på stedet blev jævnet med jorden for at gøre plads til borgen, er ligeledes tidligere blevet tolket i den retning. ${ }^{49}$

Udvides det geografiske perspektiv yderligere en anelse, er det klart, at forekomsten af en indlandslokalitet med usædvanligt righoldige detektorfund i Vendsyssel kun $18 \mathrm{~km}$ nord for Limfjorden tilføjer nye aspekter til den yngre jernalders bebyggelse i Limfjordsregionen. Hidtil har jeg behændigt undgået at inddrage bebyggelsen ved Stentinget i Vendsyssel i diskussionen. Det er imidlertid klart, at denne ikke kan ses uafhængigt af bebyggelsesudviklingen i det østlige Limfjordsområde i yngre jernalder og omvendt. Lokaliteten Stentinget ligger på en landkommunikativt gunstig placeret bakketop og ligner bortset fra sin placering $\mathrm{i}$ indlandet på mange måder de ovenfor behandlede pladser med detektorfund. Indtil videre er pladsen, når man ser bort fra intensive detektorafsøgninger, kun undersøgt i beskedent omfang. Fundmaterialet herfra består primært af detektorfundne metaller, som har en sammensætning meget lig pladserne oppe på bakkeøerne langs den østlige Limfjord. Dog synes enkelte fund fra yngre germansk jernalder og vikingetid, som f.eks. et frankisk remendebeslag af forgyldt sølv og forekomsten af en enkelt guldgubbe, at hæve denne plads lidt over kystpladserne. Hertil kommer, at sporene efter visse håndværk synes betydeligt mere massive end på de øvrige, ligesom også handelslevnene er markant fremtrædende. ${ }^{50}$

Tilsynekomsten af en større detektorplads i indlandet afføder uvægerligt spørgsmål omkring det nuværende detektorafsøgningsniveaus geografiske repræsentativitet. Har detektorfolkene været så fokuseret på de fundrige bakker langs kysterne, at de endnu mangler at afsøge arealerne længere inde i landet? Flere nye, rige, kystnære detektorpladser fra yngre jernalder fremkommet i det nordvestlige Vendsyssel demonstrerer ydermere, at en bebyggelsesudvikling som den i det østlige Limfjordsområde muligvis ikke er enestående i Nordjylland. ${ }^{51}$ Den fulde effekt af metaldetektorens revolutionerende indtog i arkæologien er således næppe set endnu. 


\section{NOTER}

I forbindelse med undersøgelsen og udfærdigelse af artiklen skylder jeg Aalborg Historiske Museum og staben der tak for god opbakning. Tak til Susanne Klingenberg ved Nationalmuseets Oldtidsafdeling for at lette tilgangen til materialet og tak til Elisabeth Munksgaard Fonden for økonomisk støtte til udarbejdelsen af artiklen.

1. F.eks. M.B. Henriksen 2000a; T. Pestell \& K. Ulmschneider 2003.

2. P. Birkedal Christensen \& E. Johansen 1992; J.N. Nielsen 2002.

3. P. Birkedal Christensen \& E. Johansen 2000; E. Johansen 1992; P.Vang Petersen 1991; K. Høilund Nielsen \& P.V. Petersen 1993.

4. Indsamlingen af materialet er sket i forbindelse med udarbejdelsen af kandidatspecialet »Detektorfund og bebyggelse omkring den østlige Limfjord« og er udelukkende sket vha. Nationalmuseets I. afdelings registreringslister. Som kontrol er omtrent en tredjedel af fundene dog besigtiget. Indsamlingen blev foretaget i 2004, og alt registreret materiale frem til udgangen af 2003 er medtaget.

5. Se f.eks. M.B. Henriksen 2000a; K. Høilund Nielsen \& P. Vang Petersen 1993.

6. P. Birkedal Christensen \& E. Johansen 2000; J.N. Nielsen 2002.

7. På begge bakker er dog ikke tale om helt skarpt afgrænsede fundkoncentrationer. Den meget store spredning af fundene på detektorpladserne gør, at de i nogen grad flyder sammen. Især pladsen Sofiendal/Gl. Hasseris er vanskelig at afgrænse fra Bejsebakken-lokaliteten mod nord. Fund af bebyggelsesspor fra yngre jernalder ved Sofiendal/Gl. Hasseris vidner imidlertid om, at her rent faktisk har været en selvstændig bebyggelse. Ved Mellemholm findes en ret markant fundkoncentration, som er relativt velafgrænset i forhold til den store Nørholmplads mod nordøst.

8. E. Johansen 1994; K. Høilund Nielsen 1994; A. Pedersen 1994.

9. J.N. Nielsen 2002, s.197-198; M. Ørsnes 1966, s. 256.

10. J.N. Nielsen 2002.

11. P. Birkedal Christensen \& E. Johansen 1992 \& 2000.

12. P. Birkedal Christensen \& E. Johansen 1992, s. 211.

13. J.N. Nielsen 2002.

14. Mens hovedparten af detektormaterialet fra Bejsebakken er blevet indleveret og dermed typebestemt og dateret i 80'erne, er stort set alt Nørholmmaterialet fra 90'erne og fremefter. I den mellemliggende periode synes der imidlertid at være sket et skred i dateringerne af fiblerne fra især overgangsperioden vikingetid/middelalder - det eneste af periodeskellene i yngre jernalder, der ikke tegner sig skarpt i fibelmaterialet. Modsat tilfældet for Bejsebakken synes næsten alt materiale fra overgangen vikingetid/middelalder fra Nørholm registreret ved Nationalmuseets afdeling for Middelalder og Renæssance, hvorfor det ikke indgår i denne undersøgelse. Dette dateringsmæssige skred synes bl.a. at være sket i forbindelse med urnesfiblerne, som i det forhåndenværende materiale er den hyppigst forekommende fibeltype fra overgangsfasen, og det er fristende at se denne ændrede registreringspraksis som et resultat af nyere publikationer, hvori netop hovedparten af urnesfiblerne bliver dateret til den tidlige middelalder (L.G. Bertelsen 1992 \& 1994).

15. Analyse foretaget af konservatorerne Per T. Hadsund og Lone B. Juul fra Aalborg Historiske Museum.

16. S. Müller 1912.

17. Fundspredningsoplysningerne anvendt i denne analyse bygger på et upubliceret kort 
lavet af Jens N. Nielsen og Jytte Ringtved allerede midt i 1980'erne. Hovedparten af fundene på Bejsebakken var dog fremkommet allerede da, og generelt må fundspredningen derfor trods den manglende opdatering formodes at være repræsentativ for det samlede registrerede materiale.

18. Detektorfolkenes fundstedsangivelser er af varierende kvalitet. For hovedparten af detektorfundene findes fundstedet afmærket på en kopi af et $4 \mathrm{~cm}$-kort. I mange tilfælde som et enkelt punkt, men ikke sjældent i form af en skravering af et større areal.

19. R.M Yorston m.fl. 1990; A. Kromann \& M. Watt 1984.

20. L. Jørgensen 2000; M.B. Henriksen 2000b.

21. P. Birkedal Christensen \& E. Johansen 1992.

22. P. Birkedal Christensen \& E. Johansen 1992, s. 212; J.N Nielsen 2002, s. 205, fig. 7i.

23. Th. Ramskou 1976. Herudover findes de omtalte detektorfundne mønter registreret under følgende numre: FP4679, FP5575, FP4360, FP.4257, FP5268, FP6303, FP5576, FP6154, FP5421, FP4376.

24. A. Kromann 1993.

25. J.N. Nielsen 2002, s. 206. For udbredelse af fibel med halvoval fodplade se f.eks. A. Bitner-Wroblévska 2001.

26. K. Høilund-Nielsen 1991, s. 133.

27. J. Ulriksen 2000 \& 2002; P. Birkedal Christensen \& E. Johansen 1992, s. 211.

28. S. Jensen 1991, s. 34, fig. 11; T. Nilsson 1992, s. 123, fig. 5f; T. Capelle 1978, s. 27-29, taf. 9 .

29. E. Johansen 1992; P. Birkedal \& E. Johansen 2000.

30. S. Young 1989, s. $38 \& 61$.

31. J. Ulriksen 2002, s. 207.

32. A. Pedersen 2004, s. 50-55.

33. Se f.eks. I. Jansson 1988.

34. I. Jansson 1988, s. 611, abb. 23.

35. I. Jansson 1988, s. 586, 609; M. Ørsnes 1966, fig. 2.

36. P. Vang Petersen, 1991, s. 55.

37. L.G. Bertelsen 1992.

38. M. Ørsnes 1966, s. 167.

39. Se f.eks. J.N. Nielsen \& M. Rasmussen 1986.

40. Se f.eks. H. Thrane 1991; L. Jørgensen 1999; L. Jørgensen \& L. Pedersen 1996; A. Branca m.fl. 1999; Watt 1991.

41. J.N. Nielsen 1999.

42. P. Birkedal Christensen \& E. Johansen 1992, 2000.

43. J.N. Nielsen 1998.

44. U. Näsman 1990, 1991; O. Crumlin-Pedersen 1991.

45. E. Johansen 1992; J.N. Nielsen 1999; J. Lund 1998.

46. P. Birkedal Christensen \& E. Johansen 2000, s. 25.

47. J. Ringtved 1997.

48. Se. f.eks. P. Sawyer 1991; E. Roesdahl 1980.

49. E. Roesdahl 1980; C.G. Schultz 1949.

50. T. Nilsson $1990 \& 1992$.

51. Arkæologiske Udgravninger i Danmark 1989, lok.nr. 180 \& Arkæologiske Udgravninger i Danmark 1992, lok.nr. 180-181. 


\section{LITTERATUR}

Bertelsen, L. Gjelssø 1992: Præsentation af Aalborg-gruppen - en gruppe dyrefibler uden dyreslyng. Aarbøger for Nordisk Oldkyndighed 1991, s. 237-261.

Bertelsen, L. Gjelssø 1994: Urnesfibler i Danmark. Aarbøger for Nordisk Oldkyndighed og Historie 1992, s. 345-370.

Bitner-Wroblévska, A. 2001: From Samland to Rogaland. East-West connections in the Baltic Basin during the early Migration Period. Warszawa.

Branca, A., B. Helgesson, B. Hårdh \& M. Tegnér 1999: Detektorfunna föremål från järnåldren. översigt av materialet vid årskiftet 1998/1999. I: B. Hårdh (red.): Fynden i centrum. Keramik, glas och metall från Uppåkra. Acta Archaologica Lundensia. Ser. in 8 , No. 30. Stockholm, s. 59-66.

Capelle, T. 1978: Die Karolingischen Funde von Schouwen. Rijksdienst voor het Oudheidkundig Bodemonderzoek.

Christensen, P. Birkedal \& E. Johansen 1992: En handelsplads fra yngre jernalder og vikingetid ved Sebbersund. Aarbøger for Nordisk Oldkyndighed og Historie 1991, s. 199-225.

Christensen, P. Birkedal \& E. Johansen 2000: The Eastern Limfjord in the Germanic Iron Age and the Viking Period. Internal Structures and External Relations. Acta Archaologica vol. 71 - 2000, s. 25-33.

Crumlin-Pedersen, O. 1991: Ship Types and Sizes AD 800-1400. I: O. Crumlin-Pedersen (red.): Aspects of maritime Scandinavia AD 200-1200. Roskilde, s. 69-82.

Henriksen, M.B. (red.) 2000a: Detektorfund - hvad skal vi med dem? Dokumentation og registrering af bopladser med detektorfund fra jernalder og middelalder. Rapport fra et bebyggelseshistorisk seminar på Hollufgård den 26. okt. 1998. Skrifter fra Odense Bys Museer vol. 5. Odense.

Henriksen, M.B. 2000b: Lundsgård, Seden Syd og Hjulby. Tre fynske bopladsområder med detektorfund. I: M.B. Henriksen (red.): Detektorfund - hvad skal vi med dem? Dokumentation og registrering af bopladser med detektorfund fra jernalder og middelalder. Rapport fra et bebyggelseshistorisk seminar på Hollufgård den 26. okt. 1998. Skrifter fra Odense Bys Museer vol. 5. Odense, s.17-60.

Jansson, I. 1988: Wikingerzeitlicher orientalischer Import in Skandinavien. Bericht der Römisch-Germanischen Kommission. Band 69. Mainz, s. 564-648.

Jensen, S. 1991: Metalfund fra vikingetidsgårdene ved Gl. Hviding og Vislev. By, marsk og geest 3, 1990. Ribe, s. 27-40.

Johansen, E. 1992: Tiden indtil 1100. I: E. Johansen, J. Kock \& B.M. Knudsen (red.). Aalborgs historie I. Aalborg, s. 16-107.

Johansen, E. 1994: Lindholm Høje og Limfjorden. I: Lindholm Høje. Gravplads og landsby. Udgivet af Selskabet for Aalborgs Historie og Aalborg Historiske Museum. Aalborg, s. 7-26.

Jørgensen, L. 1999: Fra Nutidens pløjelag til jernalderens samfund - stormænd og håndværkere i Gudme. Årbog for Svendborg og Omegns Museum 1998, s. 8-21.

Jørgensen, L. 2000: Storgården ved Tissø. Tolkning af aktivitetsområder og anlæg på grundlag af detektorfundene fra pløjelaget. I: M.B. Henriksen (red.): Detektorfundhvad skal vi med dem? Dokumentation og registrering af bopladser med detektorfund fra jernalder og middelalder. Rapport fra et bebyggelseshistorisk seminar på Hollufgård den 26. okt. 1998. Skrifter fra Odense Bys Museer vol. 5. Odense, s. 61-68. 
Jørgensen, L. \& L. Pedersen 1996: Vikinger ved Tissø. Gamle og nye fund fra et handels- og håndværkscenter. Nationalmuseets Arbejdsmark, s. 22-35.

Kromann, A. 1993: De romerske mønter. I: S. Hvass. \& B. Storgaard (red.): Da klinger $i$ muld...25 àrs arkcoologi i Danmark. Århus, s. 200.

Kromann, A. \& M. Watt 1984: Skattefundet fra Smørenge. En nedgravet skat fra folkevandringstid på Bornholm. Nationalmuseets Arbejdsmark, s. 29-41.

Lund, J 1998: Oldtidsbebyggelsen i Limfjordsområdet. Limfjordsprojektet. Rapport nr. 8. Århus, s. 141-188.

Müller S. 1912: Vendsyssel-Studier III. Kap. 18. Gravpladserne ved Donbæk og Ris. Aarbøger for Nordisk Oldkyndighed og Historie, s. 92-104.

Näsman, U. 1990: Om fjärrhandel i Sydskandinaviens yngre järnalder. Handel med glas under germansk järnålder och vikingetid. Hikuin 16, s. 89-118.

Näsman, U. 1991: Sea trade during the Scandinavian Iron Age: Its character, commodities and routes. I: O. Crumlin-Pedersen (red.): Aspects of Maritime Scandinavia AD 200-1200. Roskilde, s. 23-40.

Nielsen, J.N. 1998: Ældre jernalders bebyggelse i det østlige Limfjordsområde. Limfjordsprojektet. Rapport nr. 8. Århus, s. 271-292.

Nielsen, J.N. 1999: Maritime influences on the foundation and early history of Aalborg, Denmark. I: J. Bill \& B.L. Clausen (red.): Maritime Topography and the Medieval Town. Studies in Archaology and History 4. Copenhagen, s. 213-220.

Nielsen, J.N. 2000: Sejlflod - ein eisenzeitliches Dorf in Nordjütland. Band I-II. Aalborg.

Nielsen, J.N. 2002: Bejsebakken, a central site near Aalborg i Northern Jutland. Central Places in the Migration and the Merovingian Periods. Acta Lundensia ser. in 8o, No. 39. Stockholm, s. 197-213.

Nielsen J.N. \& M. Rasmussen 1986: Sejlflod - en jernalderlandsby ved Limfjorden. Aalborg.

Nielsen, K. Høilund 1991: Centrum og periferi i 6.-8. århundrede. Territoriale studier af dyrestil og kvindesmykker i yngre germansk jernalder i Syd- og Østskandinavien. I: P. Mortensen \& B.M. Rasmussen (red.): Fra Stamme til Stat i Danmark 2: Høvdingesamfund og kongemagt. Højbjerg, s. 127-154.

Nielsen, K. Høilund 1994: Lindholm Høje gravpladsen. I: Lindholm Høje. Gravplads og landsby. Udgivet af Selskabet for Aalborgs Historie og Aalborg Historiske Museum. Aalborg, s. 27-38.

Nielsen, K. Høilund \& P. Vang Petersen 1993: Detektorfund. I: B. Aaby et al. (red.): Da klinger i muld...25 ars arkcoologi i Danmark. Århus, s. 223-227.

Nilsson, T. 1990: Stentinget. En indlandsbebyggelse med handel og håndværk fra yngre jernalder og vikingetid. Kuml 1990, s. 19-131.

Nilsson, T. 1992: Stentinget. Skalk 1992, nr. 4, s. 3-9.

Pedersen, A. 1994: Landsbyerne på Lindholm Høje. I: Lindholm Høje. Gravplads og landsby. Udgivet af Selskabet for Aalborgs Historie og Aalborg Historiske Museum. Aalborg, s. 39-52.

Pedersen, A. 2004: Anglo-Danish Contact across the North Sea in the Eleventh Century: A Survey on the Danish Archaeological Evidence. I: J. Adams \& K. Holman (red.): Scandinavia and Europe 800-1350 - Contact, Conflict and Coexistence. Turnhout, s. 43-67.

Pestell, T \& K. Ulmscheider 2003: Markets in Early Medieval Europe. Trading and "Productive sites, 650-850. Trowbridge.

Petersen, P. Vang 1991: Nye fund af metalsager fra yngre germansk jernalder. I: P. Mor- 
tensen og B.M. Rasmussen (red.): Fra Stamme til Stat i Danmark 2: Høvdingesamfund og kongemagt. Højbjerg, s. 49-66.

Ramskou, Th. 1976: Lindholm Høje. Gravpladsen. Nordiske Fortidsminder. Serie B. Bind 2. København.

Ringtved, J. 1997: The geography of power. South Skandinavia before the Danish kingdom. I: T. Dickinson \& D. Griffiths (red.): The Making of Kingdoms. Anglo-Saxon studies in Archaeology and History 10. Oxford, s. 49-63.

Roesdahl, E. 1980: Danmarks Vikingetid. Viborg.

Sayer, P. 1991: Konger og kongemagt I: P. Mortensen \& B.M. Rasmussen (red.). Fra Stamme til Stat i Danmark 2: Høvdingesamfund og kongemagt. Højbjerg, s. 277-288.

Schultz, C.G. 1949: Aggersborg. Vikingelejren ved Limfjorden. Fra Nationalmuseets Arbejdsmark, s. 91-108.

Thrane, H. 1991: Gudmeundersøgelserne. I: P. Mortensen \& B.M. Rasmussen (red.): Fra Stamme til Stat i Danmark 2: Høvdingesamfund og kongemagt. Højbjerg, s. 67-72.

Ulriksen, J. 2000: Vikingetidige korsemaljefibler fra Roskildeegnen. ROMU. Årskrift for Roskilde Museum 1999, s. 11-30.

Ulriksen, J. 2002: Vikingetidige korsemaljefibler fra Uppåkra. Fler fynd i centrum. Material i och kring Uppåkra. Acta Archaeologica Lundensia. Ser. In 8, No. 45. Stockholm, s. 203-213.

Wamers, E. 1985: Insularer Metallschmuck in Winkingerzeitlichen Gräbern Nordeuropas. Untersuchung zur skandinavischen Westexpansion. Offa Bücher 56. Neumünster.

Watt, M. 1991: Sorte Muld. Høvdingesæde og kultcentrum fra Bornholms yngre jernalder. I: P. Mortensen \& B.M. Rasmussen (red.): Fra Stamme til Stat i Danmark 2: Høvdingesamfund og kongemagt. Højbjerg, s. 89-108.

Yorston, R.M., V.L. Gaffney \& P.J. Reynolds 1990: Simulation of Artefact movement due to cultivation. Journal of Archeological Science 17. London, s. 67-83.

Youngs, S. 1989: The work of angels. The Masterpieces of Celtic Metalwork. $6^{\text {th }}-9^{\text {th }}$ centuries AD. Somerset.

Ørsnes M. 1966: Form og Stil i Sydskandinaviens yngre germanske jernalder. Nationalmuseets skrifter. Arkæologisk-historisk række XI. København. 


\section{Detector finds and settlement}

\section{The Eastern Limfjord in Late Iron Age and Viking times}

During the past 30 years Danish fields have formed the backdrop for a silent revolution. Since the appearance of the metal detector in the 1970s, detector enthusiasts have succeeded in increasing dramatically the number of finds and known archaeological sites, especially from the Late Iron Age and Early Medieval period. This growth in the archaeological record has, among other things, led to a new understanding of settlement patterns and the general development of society.

Despite scepticism in the beginning, and a few misleading incidents involving illegal use of metal detectors, the liberal Danish legislation concerning the private use of metal detectors must therefore be termed "a success".

This has indeed also been the case in Northern Jutland, around the Limfjord. Since the very beginning of the detector adventure the Aalborg area has yielded more new finds year on year than most other areas of Denmark, being only surpassed by Bornholm and Southeast Funen. However, despite the results they have amassed, the efforts of Northern Jutland's detectorists do not seem to have been appreciated, and co-operation with the detectorists has not increased and improved in the manner seen in Southeastern Denmark.

The many detector finds from along the Limfjord have, of course, received some attention from Danish archaeologists. Especially so after excavations were carried out at a couple of the major sites, Sebbersund and Bejsebakken. However, a number of other sites have not yet received the same attention, even though they have yielded, and continue to yield, a substantial number of detector finds. These sites have been overlooked both in the field and in the archaeological literature. This article is an attempt to improve on the latter situation. It offers a presentation of the finds recovered so far and a preliminary analysis of the material.

The material recovered by detector from the region contains a great number of single stray finds. However, several sites clearly orientated towards the coasts of the Limfjord are characterised by much richer find assemblages (fig. 1). These sites are the main subject of this article, with particular focus on Late Iron Age material.

In general, the detector sites seem all to represent settlements, but when trying to analyse the detector finds and sites we are still faced with some fundamental questions. For example, it is obvious today that there is remarkably poor correlation between the overall distribution of metal objects and the settlement structures on the sites.

Thanks to the detectorists it is now possible to draw a fairly credible picture of the Late Iron Age settlement pattern around the Eastern Limfjord. This picture shows a remarkably dense concentration of rich settlements in a generally densely populated coastal zone. However, when compared to the areas rich in detector finds in the southeastern part of Denmark and Scania, this picture reveals one remarkable difference: the lack of a main centre.

The landscape and the sites Apart from drainage of low-lying meadows and a few shallow areas along the 
coast, the landscape alongside the Eastern Limfjord in the Late Iron Age resembled that of the present day. The eastern part of the Limfjord formed a narrow, winding channel, and both the northern and the southern coast consisted of wide foreshores, replaced a little further inland by moraine hills. The hills stood isolated from each other and the mainland by small rivers and low-lying, wet meadows which were flooded by the sea in the Stone Age. Øland and Gjøl actually remained islands until the $19^{\text {th }}$ century when farmers succeeded in draining the shallow waters between the hills and the mainland.

North of the fjord, the lowlands behind the hills continued for several kilometres. South of the fjord, these wet meadows were, after a few hundred metres, typically replaced by a hilly landscape dissected by river valleys.

Further to the west, the fjord at that time apparently offered two different sailing routes in and out: one to the west and a one to the northwest, through the

Sløjenkanal.

The latter has completely disappeared today and investigations suggest that the mouth of this channel silted up during the $1^{\text {st }}$ century AD. However, place names, historical records and archaeological finds indicate that the channel still played an import role during the Viking Age. Most likely the ships where simply carried over the sand bank at its mouth.

The rich detector sites dealt with in this article are Øland, Gjøl, Lindholm Høje, Humlebakken, Postgården, Thulebakken, Bejsebakken, Sofiendal/Gammel Hasseris, Nørholm, Mellemholm and Sebbersund. All but one are located on the top of the distinctive moraine hills along the Limfjord, lying typically between 1 and $3 \mathrm{~km}$ from the actual coast. In contrast to the other sites, Sebbersund is located on a small peninsula directly on the coast of the Limfjord, by the entrance to a small lagoon.

The extent to which the sites have been subjected to archaeological investigation varies considerably. Extensive excavations have been carried out at Lindholm Høje, Sebbersund, Postgården and Bejsebakken. The latter has been almost totally excavated.

Minor excavations have been carried out at Humlebakken, Thulebakken and Sofiendal/Gammel Hasseris - whereas the history of Øland, Gjøl, Mellemholm and Nørholm is characterised by an almost total lack of archaeological activity, apart from the topsoil surveys performed by the detectorists.

\section{The metal finds - chronological tendencies}

Since the only properly registered detector finds from the sites on the Eastern Limfjord are those designated as treasure trove, only these finds are included in this analysis. However, changing criteria for the designation of treasure trove have clearly affected the composition of the find material in question. The increasing number of detector finds has forced the National Museum to tighten up the designation criteria. This has led to the situation where many finds which previously were declared as treasure trove are now returned to local museums and the finders (fig. 4). Consequently, fewer finds from the more recently discovered detector sites have been declared treasure trove, making comparison with the finds from "older" sites very difficult.

Bronze brooches constitute by far the greatest part of the material chosen for this study. Out of 709 finds, 478 are brooches corresponding to $67.5 \%$. The earlier detector finds available show little typological variation, whereas variation clearly increases in finds from the later part of Late Iron Age and, especially, the Viking Age, from which there is a wide range of metal artefacts (fig. 5).

In order to compare the chronological composition of the material from the different sites, I have produced a series of dia- 
grams based on the number and dating of the brooches from each site (fig. 6.). With a few exceptions, the diagrams give an impression of marked continuity in the flow of metal objects at the sites and, in most cases, an increasing circulation of metal objects during the Late Iron Age, reaching a peak in the Late Germanic Iron Age. However, this peak is somewhat artificial since it is mainly due to the fact that only brooches have been included in the analysis. Had the entire range of finds been included, this would have shown that circulation of metals continued to grow throughout the Viking Age.

Øland, Gjøl and Sebbersund do not fit this picture of continuity. The detector finds from these sites consist, almost exclusively, of objects from the Late Germanic Iron Age and Viking Age. However, Øland and Gjøl belong to the most recently discovered detector sites and the finds from them can hardly be expected to give a fully representative picture of the metal objects present in the soil here.

In contrast, Sebbersund is a well-known "old" site and a similar, but more thorough, analysis of the brooches from the site, including the ones recovered during excavations, has produced the very same result. Activities at Sebbersund seem, therefore, to have been very limited in the Germanic Iron Age, before blossoming in the Viking Age and then ceasing almost completely around AD 1100.

Furthermore, on the topic of continuity, the finds from all the rich detector sites on the Eastern Limfjord also include various amounts of medieval artefacts and, in most cases, early medieval churches or monasteries are located nearby. Activities on these sites carried on well into the medieval period.

\section{The distribution of the finds - size and structure of the sites}

Half of the rich detector sites on the Eastern Limfjord have been subjected to exca- vation and in all cases settlement remains were revealed. Similar excavations in other parts of Denmark have shown the same pattern and it seems safe to assume that the metal items present in the topsoil at the rich detector sites analysed in this article are the result of settlement remains under degradation.

Furthermore, since cremation graves were the dominant burial type during a major part of Late Iron Age in Northern Jutland, one would expect to find a large number of fire-damaged metal objects among the detector finds if these originated from burial sites. This is not the case.

The quality of the information on find site varies greatly from find to find and the recorded geographical information presents little opportunity for inferences to be made concerning the structure of each site. However, the overall distribution of the finds clearly poses an interesting problem. On all of the rich sites, with the exception of Sebbersund, the metal objects lie scattered over huge areas. These are far greater than those which can be expected to conceal traces of prehistoric settlement. The detector site on Nørholm hill is the largest so far, covering approximately 400 acres.

The Bejsebakken case underlines the phenomenon; this settlement has been almost totally excavated. If the extent of the settlement is compared with the distribution of detector finds from the hill it is obvious that there is a concentration of metal objects recovered from the topsoil above the remains of the settlement, but it is equally clear that a considerable number of finds have been detected outside this area (fig. 7).

The large number of metal objects found outside the area with archaeological remains of the settlement probably reflects some sort of adjacent activity area connected to the farmsteads on the top of the hill. However, the area in question covers several acres. In my opinion it seems most 
likely that the surprisingly wide distribution of the metal objects is due to the use of settlement waste as manure on the fields in the vicinity of the farmsteads.

A wide distribution of the detector finds is, incidentally, a very common phenomenon. Along with a similar topographic setting, this feature is shared by almost all the large detector sites on the Eastern Limfjord. It therefore seems likely that agriculture played an important role in the economy of these settlements.

Only the settlement at Sebbersund does not conform to this picture. In contrast to the other sites, the detector finds here seem to be concentrated within an extremely limited area. This situation, however, corresponds well with the excavation results from the 1980s which led to the interpretation of the settlement structures as remains of a trading place without traces of any ordinary agrarian settlement.

\section{Crafts and Trade}

Obviously, only a very limited number of the activities which took place at the Iron Age settlements can be revealed by the use of metal detectors. However, a few of the metal objects indicate the presence of metal crafts and trade.

Generally, the direct indicators of trade are sparse. Means of payment such as coins and pieces of silver are rare and only Sebbersund has yielded a significant number of balance weights. Furthermore, all of the finds belonging to this category are from the Viking Age. However, a substantial number of foreign metal objects clearly point to the fact that the sites on the Limfjord were part of a far-reaching communication network (figs. 8 and 9). Excavations at several of the sites have also recovered various imported goods, and trade must have been a common phenomenon.

The imported finds seem to reflect a contact network which evolved through time. In the Germanic Iron Age, the network seems mainly to have covered the rest of Scandinavia, whereas the British Isles and the northwestern part of Continental Europe, especially the area around the mouth of the Rhine, were clearly also included in the Viking Age. However, not only the direction of the traffic seems to have evolved. When looking at the number and character of the objects found on the sites, it seems obvious that the traffic increased in the course of the Late Iron Age and that trade in bulk goods began and expanded through the Viking age.

Crafts are generally poorly represented in the detector finds. A few items, such as raw materials in the form of small pieces of gold and silver, half-finished brooches, a matrix for the production of bracteates and three identical brooches at one site, indicates the in situ production of jewellery at the sites. This conclusion is also supported by the fact that several types of brooches and some ornamental elements exclusively or mainly occur on the Eastern Limfjord.

As could be expected, a much broader spectrum of crafts has been demonstrated through excavations at some of the sites and, apart from showing the traditional variation of crafts, the excavation results generally seem to demonstrate a marked focus on the production of textiles. At Sebbersund and Bejsebakken the number of pit-houses exceeds several hundreds and the majority of these were clearly used for the production of textiles. This production must definitely have exceeded what could possibly have been needed locally.

\section{Regional settlement pattern and interpretation of the rich sites}

At present, it is only possible to draw a fairly credible picture of the Late Iron Age settlement pattern on the Eastern Limfjord by including the considerable number of single detector finds from the region. On this basis, the area seems to have been quite densely populated with a series of richer settlements along the coasts of the fjord (fig. 11). 
The lack of inland settlements equally rich in metal finds seems to indicate that the coast-near settlements on the fjord served, in some respects, as central places relative to the settlements further inland.

It is obvious that the circulation of metal objects varied considerably from settlement to settlement and from period to period. Despite these variations, none of the detector sites has so far yielded an assemblage which allows us to assign any of the settlements to a position elevated markedly above the others in the settlement system for the region. However, the considerable variation in the number of finds from the different sites clearly points to the fact that some settlements were more successful than others. This seems to have been very much the case on the Nørholm and the Bejsebakken hills, especially in the Late Germanic Iron Age, during which the circulation of metal objects here accelerated markedly relative to the other sites.
The lack of a pronounced main centre in a generally wealthy region stands in remarkable contrast to contemporary settlement patterns known from the southeastern part of Denmark and Scania. These latter areas were apparently characterised by a society of a much more hierarchical nature and by settlement patterns including easily recognisable centres mainly characterised by extreme concentrations of rich gold and silver finds along with the presence of unusual imports.

The development of a highly stratified society seems, therefore, to have proceeded at a somewhat slower pace in the Limfjord region. Together with the growing importance of the Limfjord for communication, this led to the characteristic settlement pattern which included a large number of settlements of centre-like character located along the coasts of the eastern part of the fjord in the Late Iron Age.

Torben Trier Christiansen Aalborg Historiske Museum 